\title{
Rock magnetic and paleointensity results from Mesozoic baked contacts of Armenia
}

\author{
V. V. Shcherbakova ${ }^{1}$, M. Perrin ${ }^{2}$, V. P. Shcherbakov ${ }^{1}$, V. E. Pavlov ${ }^{3}$, A. Ayvaz'yan ${ }^{4}$, and G. V. Zhidkov ${ }^{1}$ \\ ${ }^{1}$ Borok Geophysical Observatory, Schmidt Institute of Physics of the Earth, Russian Academy of Sciences, Borok, Russia \\ ${ }^{2}$ Geosciences Montpellier, UMR CNRS/UM2 5243, Université Montpellier II, France \\ ${ }^{3}$ Schmidt Institute of Physics of the Earth (IPE), Russian Academy of Sciences, Moscow, Russia \\ ${ }^{4}$ Yerevan State University, Departament of Geology, Armenia
}

(Received December 24, 2007; Revised March 17, 2008; Accepted March 20, 2008; Online published January 23, 2009)

\begin{abstract}
Samples were obtained from three baked contacts and one lava flow along the upper Turonian-lower Coniacian Tovuz section, two baked contacts along the upper Coniacian-lower Santonian Paravakar section in the northern part of Armenia, and three baked contacts along the Titonian-Valanginian Kafan section in southern Armenia. A total of 130 samples were studied. Updated mean paleomagnetic poles were calculated for the Upper Cretaceous Tovuz-Paravakar sections $\left(65.6^{\circ} \mathrm{N}, 162.2^{\circ} \mathrm{E}, A_{95}=4.3\right.$, paleolatitude $\left.=27.0 \pm 3.4^{\circ}\right)$ and the Upper JurassicLower Cretaceous Kafan section $\left(61.7^{\circ} \mathrm{N}, 158.9^{\circ} \mathrm{E}, A_{95}=4.8^{\circ}\right.$, paleolatitude $\left.=24.7 \pm 3.8^{\circ}\right)$. Paleointensity determinations could be estimated from two of the upper Cretaceous and three of the Upper Jurassic-Lower Cretaceous baked contacts, corresponding to a $30 \%$ success rate. The mean virtual dipole moments obtained were low $\left(1.7-5.5 \times 10^{22} \mathrm{~A} \mathrm{~m}^{2}\right)$, which is in agreement with data published by Bol'shakov and Solodovnikov (1981a, 1983) for the same sections (3.0-4.4 $\times 10^{22} \mathrm{~A} \mathrm{~m}^{2}$ ). Our results support the hypothesis of the Mesozoic Dipole Low, even though the overall data are widely dispersed.
\end{abstract}

Key words: Paleointensity, Armenia, Cretaceous, baked contacts, Thellier method.

\section{Introduction}

Knowledge of the basic characteristics of the ancient geomagnetic field provides valuable information about the formation and evolution of the solid inner core, mantle, and outer shells of the Earth. In particular, the analysis of average paleontensity variation in the geologic past is a subject of active discussion among scientists. However, our current knowledge of the origin of the geomagnetic field and its origin in the Earth's core is seriously limited by the quantity and quality of palaeointensity records. Indeed, in the updated versions of the World Paleointensity Database (Perrin and Shcherbakov, 1997; Perrin et al., 1998; Perrin and Schnepp, 2004; Shcherbakov and Sycheva, 2006), there have been fewer than 3500 records for the entire geologic time scale (0-3500 Ma) obtained from individual cooling units since the beginning of paleointensity studies in the late 1940s. About one third of these records have been published by Bol'shakov and Solodovnikov, between 1960 and 2001, from the former Soviet Union bloc. The main advantage of these studies is that they were almost exclusively carried out using the most reliable Thellier method (Thellier and Thellier, 1959) on volcanic rocks and combined with an investigation of baked contacts.

Modern paleointensity database analyses have revealed the necessity of data selection on the basis of commonly accepted criteria of reliability. One of the most com-

Copyright (c) The Society of Geomagnetism and Earth, Planetary and Space Sciences (SGEPSS); The Seismological Society of Japan; The Volcanological Society of Japan; The Geodetic Society of Japan; The Japanese Society for Planetary Sciences; TERRAPUB monly used criterium is the result of the so-called 'pTRM checks', which is supposed to show the occurrence of mineralogical changes in the rocks during Thellier experiments. Bol'shakov and Solodovnikov did not perform the classic pTRM check procedure but a simple version of the test: "In control measurements, the partial $\operatorname{TRM}\left(300,20^{\circ} \mathrm{C}\right)$ and susceptibility vary by no more than 10 to $15 \%$, which indicates a good stability of the ferromagnetic minerals of the rocks in laboratory heatings" (Bol'shakov and Solodovnikov, 1983, p. 979). This procedure was usually performed after the $600^{\circ} \mathrm{C}$ Thellier step (personal communication to S. V. V. and S. V. P.). Nevertheless, due to the absence of the classic pTRM check, the numerous works published by Bol'shakov and Solodovnikov have been often rejected from modern compilations (e.g., Selkin and Tauxe, 2000; Tauxe and Staudigel, 2004), which has resulted in a substantial uncertainty in the interpretation of the Phanerozoic paleointensity determinations. Indeed, data published by Bol'shakov and Solodovnikov show a distinctive bimodal distribution of paleointensity for the last $300 \mathrm{Ma}$ (Perrin and Shcherbakov, 1997; Shcherbakov and Sycheva, 2006), which might be related to two different regimes of the geodynamo, with a large number of data showing low Mesozoic Dipole intensities. However, with the rejection of the Russian data, this distribution is not as distinct, leading some authors to propose high Mesozoic values (Tauxe and Staudigel, 2004; Tarduno and Cottrell, 2005).

As long as it is not possible to use the raw data or spare specimens from Bol'shakov and Solodovnikov, the best ap- 


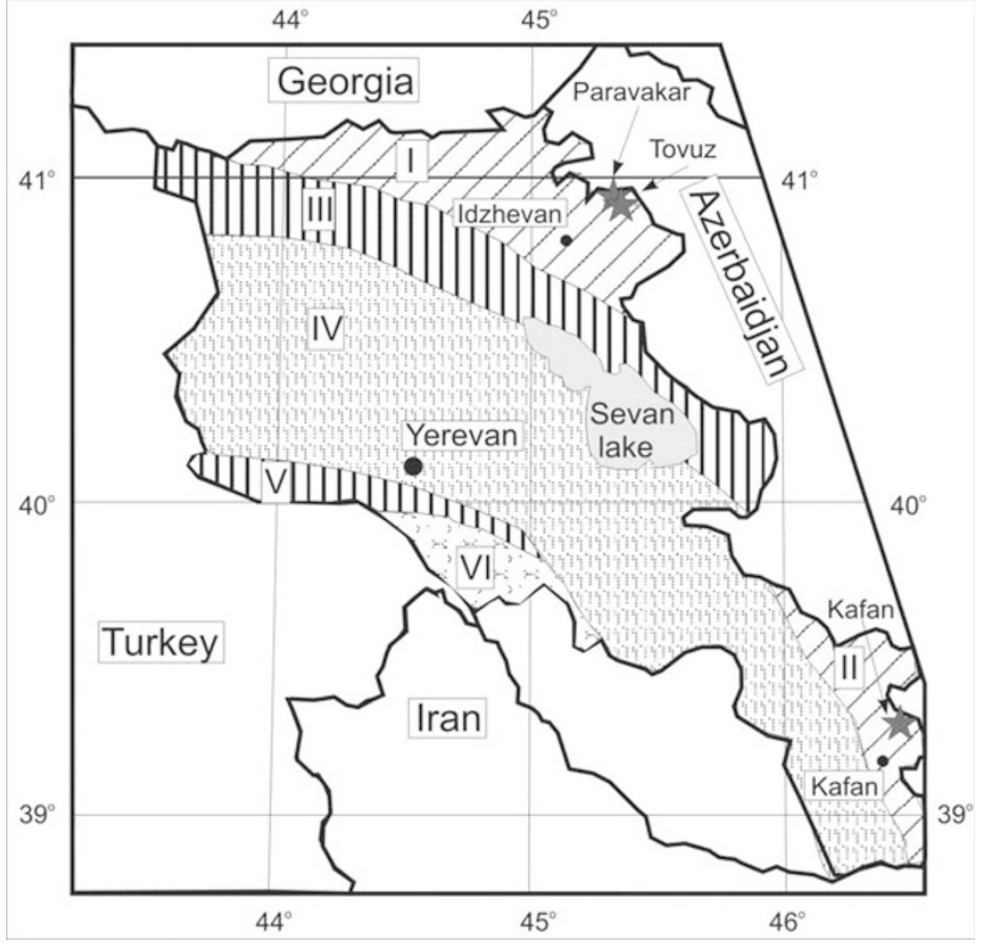

Fig. 1. Localization of the studied sections. I: Somkheto-Karabach island complex zone; II: Kapan island complex; III: Amasia-Sevan ophiolitic zone; IV: Hankavan-Zangezour Late Precambrian and Paleozoic basement intruded by granitoids and alkaline volcanic and magmatic complex of Paleogene age; V: Vedi ophiolitic zone; VI: Pre-Araxian zone (northern part of the Iran microplate).

proach for assessing the reliability of their paleointensity data is to resample some of their sections and subject them again to Thellier experiments using more recent instruments and experimental methods. This was the purpose of a joint French-Russian expedition carried out in Armenia in 2006, during which volcanic rocks and related baked contacts were sampled. In this paper, we present the paleointensity results obtained on part of the Armenian collection, mainly baked contacts. The results from the rest of the collection, mainly lava flows, will be published elsewhere after the experiments have been completed.

\section{Geology and Sampling}

Specimens presented in this analysis were sampled along three sections located in the north-eastern part (Tovuz, Paravakar sections) and south-eastern part (Kafan section) of Armenia (Fig. 1). The volcanic and sedimentary rocks of these sections belong to the Somkheto-Karabakh and Kafan island arc complexes, respectively, which are important constituents of the Jurassic-Cretaceous Lesser Caucasus island arc system (Avanesyan and Avanesyan, 2006).

Volcanic and volcanogenic-sedimentary rocks of the upper member of the Somkheto-Karabakh island arc complex are exposed along the Tovuz and Paravakar sections. This member, Upper Cretaceous in age, has a total thickness of about $1500-1800 \mathrm{~m}$ and is divided into three strata: a lower one formed by terrigenous-carbonaceous flysch (Cenomanian to Lower Turonian), a middle one made by volcanic and volcanogenic rocks (Upper Turonian to Lower Santonian), and an upper strata composed of acid volcanogenic rocks (Upper Santonian) (Chubaryan and Arakelyan, 1962; Shmidt et al., 1982). Our sampling was focused on the best exposed middle strata, with the Tovuz section being within the Upper Turonian to Lower Coniacian part of the section and the Paravakar section in the Upper Coniacian to Lower Santonian part (Shmidt et al., 1982). During the emplacement of the lava flows, the hot magma pouring on top of the tuffs and/or sedimentary rocks baked the contacts, a fairly often occurrence in Armenia, over a thickness of about $0.2-0.5 \mathrm{~m}$ or even more. These baked contacts differ markedly from the other rocks of the sections by their purple-red coloration. As their magnetic properties can be extremely useful for paleointensity experiments, they were sampled whenever possible.

The Tovuz section $\left(40^{\circ} 46^{\prime} \mathrm{N} ; 45^{\circ} 23^{\prime} \mathrm{E}\right)$ is composed of volcanic rocks (70\%; basalt, andesite-basalt, and different types of tuff) and sediments (30\%; mainly sandstone, tuff sandstone, and limestone). Six sites were sampled along the section, three (T1, T3, and T5) of which were in lava flows (29 samples) and three (T2, T4, and T6) in baked contacts (32 samples).

In the Paravakar $\left(40^{\circ} 59^{\prime} \mathrm{N} ; 45^{\circ} 21^{\prime} \mathrm{E}\right)$ section, the relative proportion of sedimentary rocks decreases, and most of the section is represented by volcanic and volcanogenic rocks (basalt, andesite-basalt, and tuff). Tuff sandstones are also found. Three sites were sampled along the Paravakar section: two sites (P1, P3) in baked contacts (20 samples) and one site (P2) in a lava flow (7 samples).

The Kafan section $\left(39^{\circ} 30^{\prime} \mathrm{N} ; 46^{\circ} 47^{\prime} \mathrm{E}\right)$ was sampled along the Karmrakar segment of the Kapan-Yerevan road where volcanics and carbonate rocks of the KarmrakarTapasar formation, Titonian-Valanginian in age, can be found (Hakobyan, 1963; Uspenskaya et al., 1984). This 1800 -m-thick section is mainly composed of alternating 

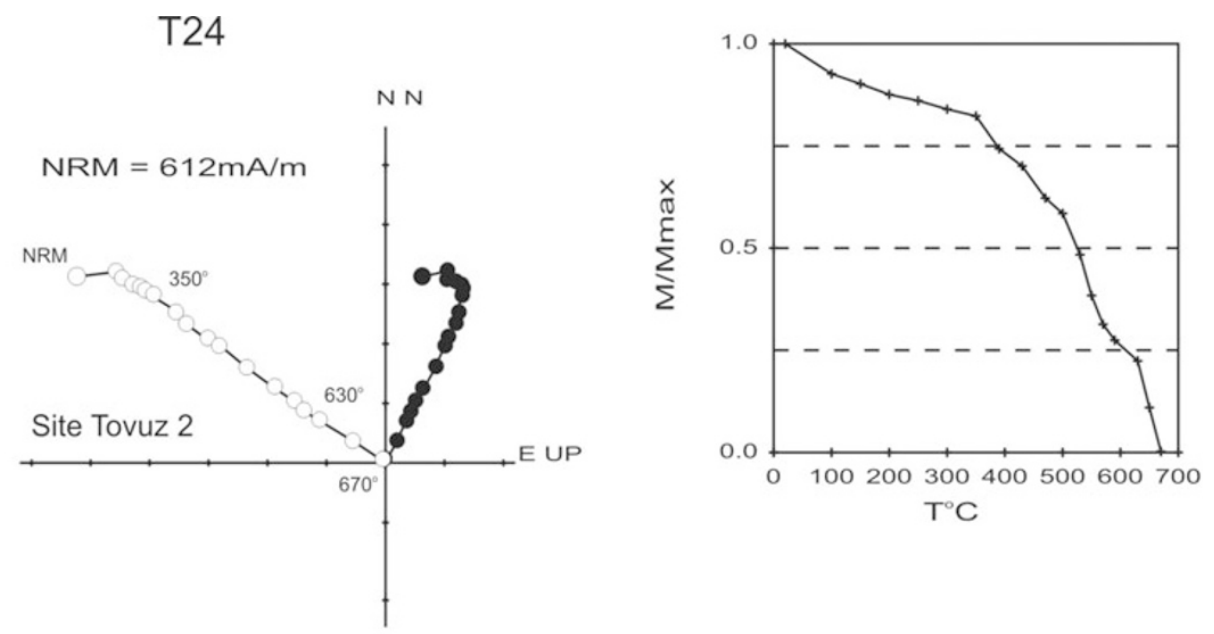

\section{T40}
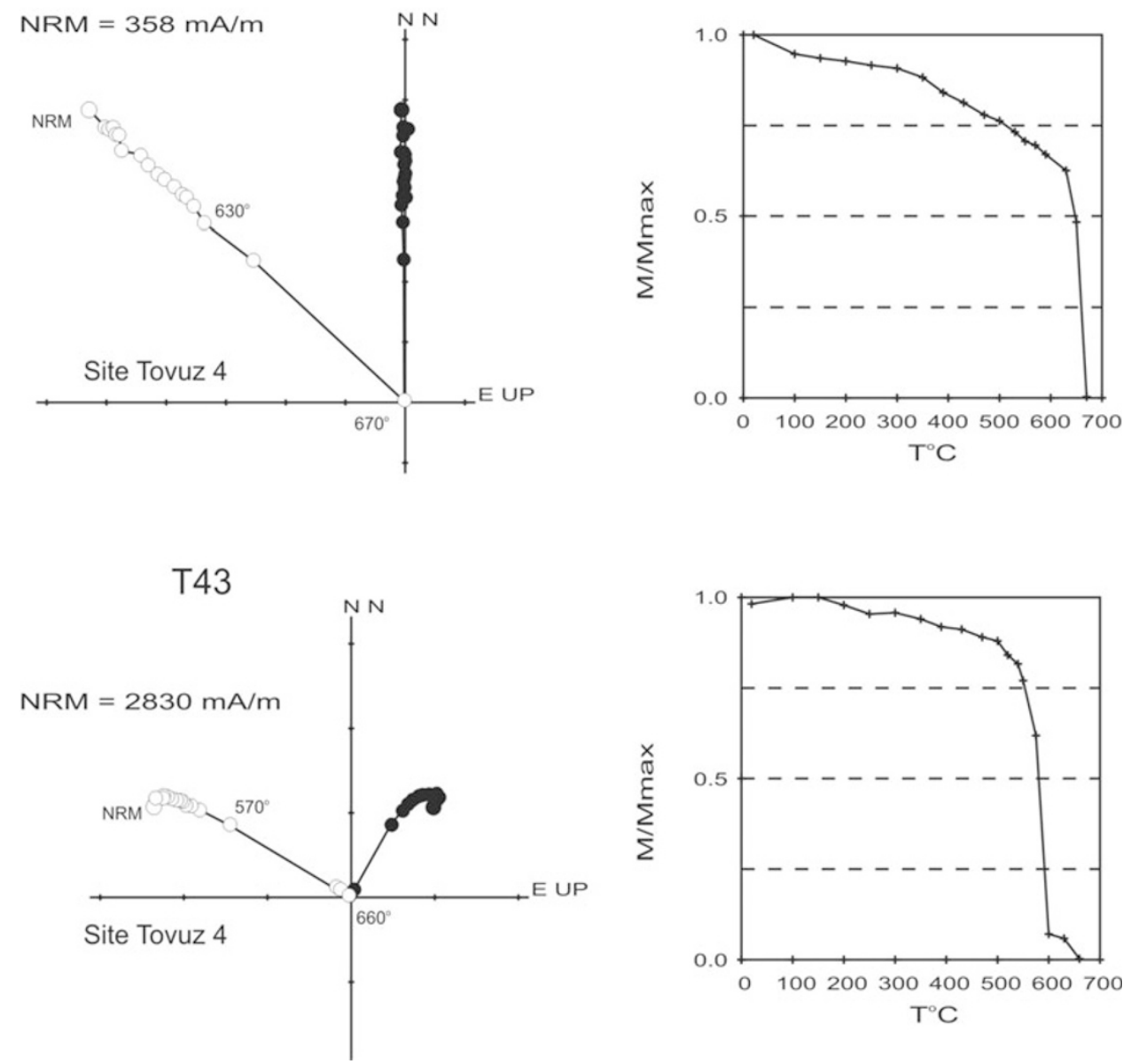

Fig. 2. Example of thermal demagnetization (orthogonal plot and normalized demagnetization curve) for samples from baked contacts of Tovuz (T24, T40, T43, T78), Paravakar (P110), and Kafan (K254) sections. Solid and open symbols on the orthogonal diagram denote horizontal and vertical projections, respectively.

basalts, andesite-basalts, trachyandesites, trachyandesitebasalts with organic arenaceous limestone, tuff gravellites, tuff conglomerates, and tuff breccias horizons. The rocks are part of the eastern limb of the Kafan anticline, which dips towards the northwest at angles of $25-30^{\circ}$. Four sites have been sampled along the Kafan section: three sites (K1, $\mathrm{K} 2, \mathrm{~K} 3$ ) in baked contacts (56 samples) and one site (K4) in a lava flow (10 samples).
Tilt corrections were estimated in the field for individual units as often as possible, resulting in an estimation of the regional tilt dipping toward the northwest to be at angles of $20-30^{\circ}$. In total, three baked contacts and one flow sampled along the Tovuz section, two baked contacts along the Paravakar section, and three baked contacts along the Kafan section were studied (130 samples), and results are reported here. 
T78

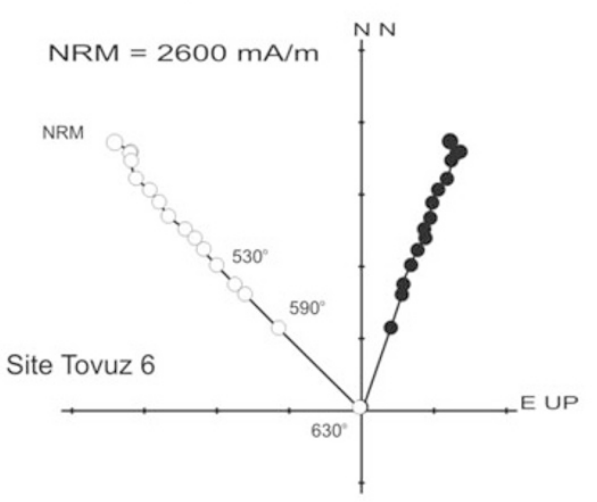

P110

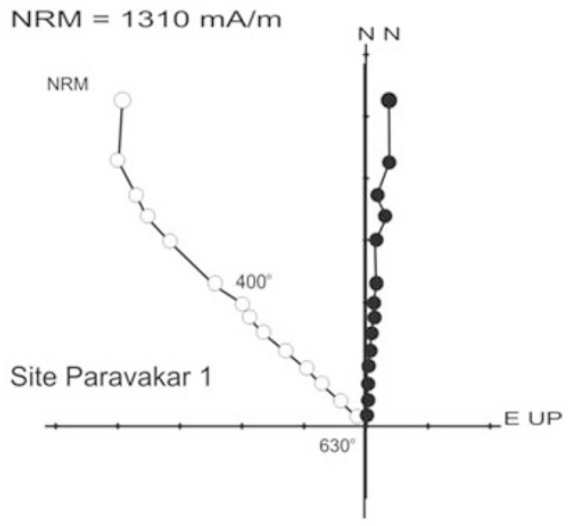

K254

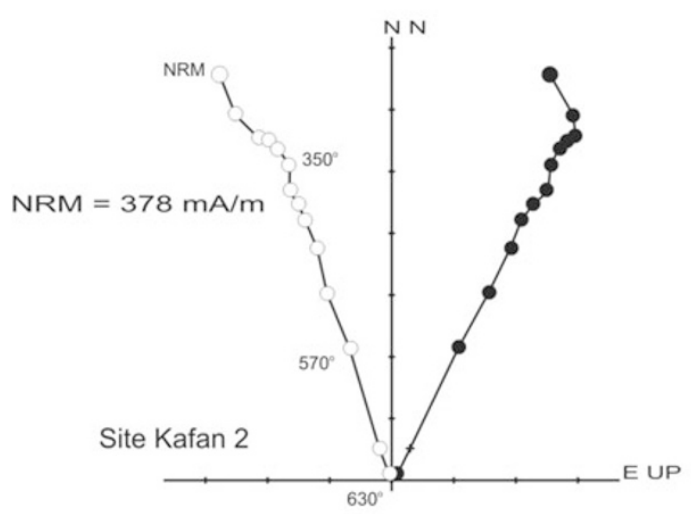

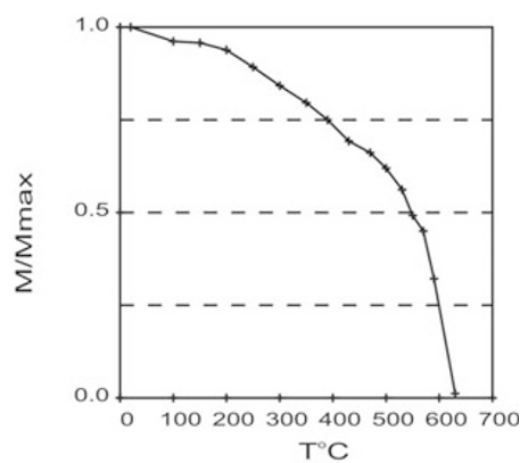
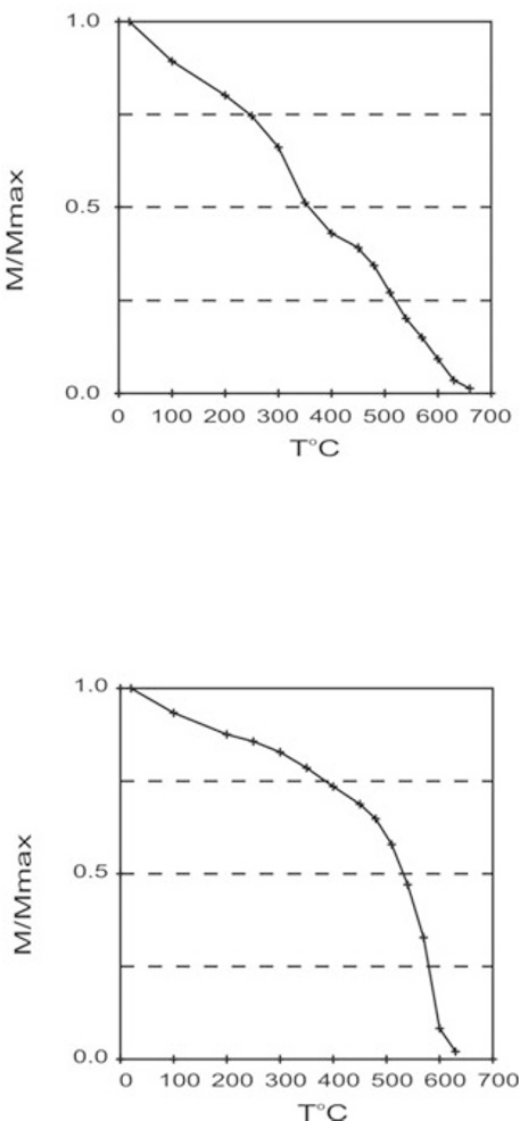

Fig. 2. (continued).

\section{Paleomagnetic Analysis}

Most of the studied samples reveal very simple demagnetization behavior. Some of these display two components of magnetization (Fig. 2, samples T24): (1) a low temperature component that has a direction close to the present day field direction and is likely to be recent and of viscous origin; (2) a high temperature component. However, most of the time, only one component of magnetization remains after removal of the unstable part of the magnetization by heating at $100-150^{\circ} \mathrm{C}$ (Fig. 2, samples T40, P110, and K254). This component is similar to the high temperature component of samples displaying two components of magnetization. It decays towards the origin in the orthogonal plots and, in both cases, represents the characteristic remanent magnetization (ChRM) of the samples. The maximum unblocking temperatures of these ChRMs vary from one contact to the other. Whereas a maximum unblocking temperature around $600-640^{\circ} \mathrm{C}$ predominates in samples from the Paravakar and Kafan sections (Fig. 2, samples P110, K254), the ChRMs in samples from the Tovuz section disappear completely only in the vicinity of $660-670^{\circ} \mathrm{C}$ (Fig. 2 , samples T24, T40, T43). A difference in the unblocking temperatures spectrum is also observed. For example, the major part of the ChRM from the Tovuz 2 contact (Fig. 2, sample T24) is destroyed relatively gradually within the temperature range $350-670^{\circ} \mathrm{C}$, while in samples from the Tovuz 4 

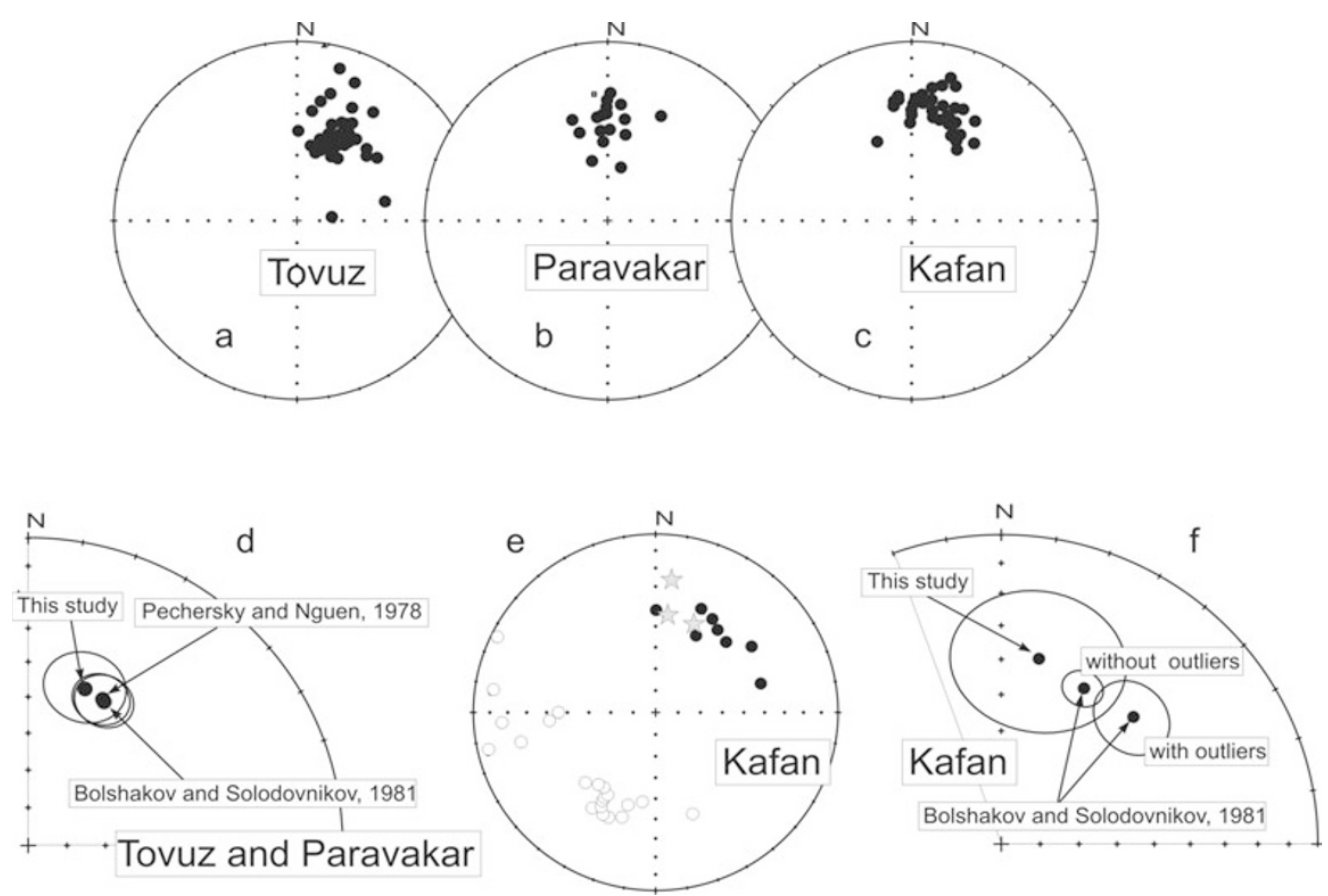

Fig. 3. Equal area plots of ChRM directions from (a) Tovuz, (b) Paravakar, and (c) Kafan sections; (d) comparison of Tovuz-Paravakar mean directions obtained in this study with those of Pechersky and Nguen (1978) and Bol'shakov and Solodovnikov (1981a); (e) comparison of site mean directions obtained for the Kafan section in this study (grey stars) with samples directions of Bol'shakov and Solodovnikov (1983); open/filled circles represent, respectively, reversed/normal polarities; (f) comparison of Kafan mean directions obtained in this study with those of Bol'shakov and Solodovnikov (1983); the directions with westerly declinations being considered as transitional are not included in their Kafan mean direction.

contact, more than half of the total magnetization often survives at a temperature of $650^{\circ} \mathrm{C}$ (Fig. 2, sample T40). Judging from the values of the maximum unblocking temperatures, the dominant remanence carrier in the studied rocks is magnetite oxidized to variable degrees to maghemite. It is interesting to note that in some samples, unoxidized magnetite with a Curie point close to $580^{\circ} \mathrm{C}$ is observed together with oxidized magnetite (Fig. 2, sample T43).

In all studied contacts, the mean directions of the ChRM have moderate positive inclinations and north-north-east declinations (see Fig. 3(a-c); Table 1).

The mean Tovuz-Paravakar direction obtained in this study is in very good agreement with the paleomagnetic directions presented by Bol'shakov and Solodovnikov (1981a) for these two sections (Fig. 3(d)). As the tilt corrections applied to our different outcrops were not sufficiently different to allow for a meaningful fold test, we refer to the results obtained by Nguen (1978) and Pechersky and Nguen (1978) for the Turonian-Santonian rocks of nearby sections, which are virtually identical to our paleomagnetic directions (Table 1, Fig. 3(d)), to support the Late Cretaceous age of the ChRMs isolated in the Tovuz and the Paravakar sections. The demagnetization experiments carried out in the Nguen (1978) and Pechersky and Nguen (1978) studies clearly demonstrate that even the limited magnetic cleaning used by these authors was sufficient to isolate the ChRM. The prefolding age of the magnetization, the positive result of a reversal test, as well as the results of magnetomineralogical studies support both the primary origin of the ChRMs obtained by Pechersky and Nguen (1978) and the primary origin of the ancient magnetization isolated in our study in the Tovuz and the Paravakar sections.
The baked contacts from the Kafan section had a mean ChRM direction (Fig. 3(e, f)) that was statistically indistinguishable $\left(\gamma / \gamma_{\mathrm{c}}=12.7^{\circ} / 14.3^{\circ}\right.$; McFadden and McElhinny, 1990) from that obtained earlier by Bol'shakov and Solodovnikov (1983), after seven outliers with westerly declinations had been removed from the data set (see Fig. 3(e)). These directions, significantly different from all other normal and reverse directions, do not likely reflect the true direction of the ancient geomagnetic field and were interpreted by Bol'shakov and Solodovnikov (1983) as reflecting a transitional state of the geomagnetic field. The similarity of the directions recorded by the outliers can be explained in part by the fact that at least five of them were obtained from continuous units along a section and, possibly, acquired during a relatively short time interval. Bol'shakov and Solodovnikov's study also shows that whereas the directions of magnetization are the same for the baked and unbaked zones, the intensity of magnetization between the zones decreases by factor of up to 5, leading to a positive baked contact test (McElhinny and McFadden, 2000). Our comparison of the normal and reversed mean site directions, obtained by Bol'shakov and Solodovnikov (1983), also indicates that the reversal test is positive $\left(\gamma / \gamma_{\mathrm{c}}\right.$ $\left.=6.3^{\circ} / 10.0^{\circ}\right)$. Hence, both the magnetization isolated by Bol'shakov and Solodovnikov (1983) and the magnetization isolated in the baked contacts from the Kafan section in our study can be considered to be primary.

Evidence of a primary origin for the ChRMs isolated in the Tovuz, Paravakar, and Kafan sections enables us to consider these rocks for paleointensity experiments. By averaging the data obtained from our study with those of the earlier studies of of Nguen (1978), Pechersky and 
Table 1. Paleomagnetic directions

\begin{tabular}{|c|c|c|c|c|c|c|c|c|c|}
\hline \multirow{2}{*}{ Site } & \multirow{2}{*}{$N$} & \multicolumn{4}{|c|}{ In situ } & \multicolumn{4}{|c|}{ Tilt corrected } \\
\hline & & $D$ & $I$ & $k$ & $\alpha_{95}$ & $D$ & $I$ & $k$ & $\alpha_{95}$ \\
\hline \multicolumn{10}{|c|}{ Northern Armenia } \\
\hline \multicolumn{10}{|c|}{ Upper Cretaceous (Turonian-Coniacian-Santonian, $\sim 90-84 \mathrm{Ma}$ ) } \\
\hline \multicolumn{10}{|c|}{ This study } \\
\hline Tovuz_2 & 5 & 52.7 & 49.3 & 175 & 5.8 & 23.3 & 54.6 & 175 & 5.8 \\
\hline Tovuz_4 & 8 & 41.9 & 50.1 & 20 & 12.7 & 20.3 & 45.1 & 20 & 12.7 \\
\hline Tovuz_5 & 2 & 57.4 & 48.5 & - & 一 & 34.4 & 48.7 & - & - \\
\hline Tovuz_6 & 15 & 44.4 & 43.9 & 53 & 5.3 & 26.3 & 40.3 & 53 & 5.3 \\
\hline Paravakar_l & 16 & 27.6 & 53.2 & 38 & 6.0 & 359.0 & 45.5 & 38 & 6.0 \\
\hline Paravakar_3 & 2 & 20.7 & 50.0 & 一 & 一 & 14.4 & 29.8 & - & - \\
\hline Mean (sites level) & 6 & 41.2 & 49.9 & 71 & 8.0 & 19.3 & 44.5 & 46 & 10.0 \\
\hline \multicolumn{10}{|c|}{ Bol'shakov and Solodovnikov (1981a)* } \\
\hline Mean Tovuz + Paravakar (sites level) & 8 & & & & & 27.2 & 46.1 & 58 & 7.3 \\
\hline \multicolumn{10}{|c|}{ Pechersky and Nguen (1978)* } \\
\hline Mean Tovuz region (samples level) & 184 & & & & & 20 & 46 & 36 & 11 \\
\hline Mean Tovuz region (sites level) & 5 & & & & & 26.0 & 46.0 & 118 & 7.1 \\
\hline \multicolumn{10}{|c|}{ This study + Bol'shakov and Solodovnikov (1981a) + Pechersky and Nguen (1978) } \\
\hline Mean direction (sites level) & 19 & & & & & 24.4 & 45.6 & 64 & 4.2 \\
\hline Mean pole & \multicolumn{9}{|c|}{$\begin{array}{c}\text { Plat }=65.6^{\circ} \mathrm{N} ; \text { Plong }=162.2^{\circ} \mathrm{E} ; d p / d m=3.4^{\circ} / 5.3^{\circ} ; \\
A_{95}=4.3^{\circ} ; \text { paleolatitude }=27.0 \pm 3.4^{\circ}\end{array}$} \\
\hline \multicolumn{10}{|c|}{ Southern Armenia } \\
\hline \multicolumn{10}{|c|}{ Upper Jurassic-Lower Cretaceous (Titonian-valanginian, 150-136 Ma) } \\
\hline Kafan_l & 12 & 36.6 & 58.8 & 69 & 5.3 & 5.6 & 44.3 & 69 & 5.3 \\
\hline Kafan_2 & 14 & 21.7 & 42.6 & 121 & 3.6 & 6.5 & 25.7 & 122 & 3.6 \\
\hline Kafan_3 & 8 & 54.5 & 51.7 & 71 & 6.6 & 23.0 & 45.5 & 71 & 6.6 \\
\hline Mean for sites & 3 & 36.6 & 51.9 & 37 & 20.6 & 11.2 & 38.8 & 37 & 20.6 \\
\hline \multicolumn{10}{|c|}{ Bol'shakov and Solodovnikov (1983)* } \\
\hline Kafan** R-polarity (sites level) & 13 & & & & & 208.2 & -42.7 & 95 & 4.3 \\
\hline Kafan N-polarity (sites level) & 8 & & & & & 36.8 & 43.1 & 23 & 11.7 \\
\hline Kafan** Mean (sites level) & 21 & & & & & 27.1 & 42.9 & 41 & 5.0 \\
\hline \multicolumn{10}{|c|}{ This study + Bol'shakov and Solodovnokov (1983) } \\
\hline Mean Kafan** Direction & 24 & & & & & 28.8 & 42.6 & 38 & 4.9 \\
\hline $\begin{array}{c}\text { Mean Kafan** } \\
\text { Paleomagnetic pole }\end{array}$ & & & at $=6$ & $\begin{array}{l}{ }^{\circ} ; \mathrm{P} \\
=4 .\end{array}$ & $\begin{array}{l}\mathrm{g}=15 \\
\text { paleol }\end{array}$ & $\begin{array}{l}{ }^{\circ} \mathrm{E} ; d p / \\
\mathrm{ude}=2\end{array}$ & $\begin{array}{l}=3.8^{\circ} \\
\pm 3.8^{\circ}\end{array}$ & & \\
\hline
\end{tabular}

*Pechersky and Nguen (1978), Bol'shakov and Solodovnikov (1981a, 1983) did not present in situ paleomagnetic direction. **Calculated without outliers (see capture for Fig. 3(e)). The sites which gave accepted palaeointensity results are marked in italics.

Nguen (1978), and Bol'shakov and Solodovnikov (1981a, 1983), we obtained updated mean paleomagnetic poles for the Upper Cretaceous Tovuz-Paravakar sections $\left(65.6^{\circ} \mathrm{N}\right.$, $162.2^{\circ} \mathrm{E}, A_{95}=4.3$, paleolatitude $\left.=27.0 \pm 3.4^{\circ}\right)$ and the Upper Jurassic-Lower Cretaceous Kafan section $\left(61.7^{\circ} \mathrm{N}\right.$, $158.9^{\circ} \mathrm{E}, A_{95}=4.8^{\circ}$, paleolatitude $=24.7 \pm 3.8^{\circ}$ ).

Our study is the first one in the region limited by latitudes $38^{\circ} \mathrm{N}$ and $42^{\circ} \mathrm{N}$ and longitudes $43^{\circ} \mathrm{E}$ and $47^{\circ} \mathrm{E}$, where Late Jurassic and Late Cretaceous paleomagnetic directions have been obtained by use of full demagnetization and principal component analysis. Nevertheless, our directions and their corresponding paleomagnetic poles are often in a very good agreement with the results of previous studies, not cited above, carried out on coeval rocks in nearby areas (e.g., Sirunyan et al. quoted in Khramov, 1975; Khalafov quoted in Khramov, 1986; Guseynov et al. quoted in Khramov, 1989).

\section{Rock Magnetic Properties}

The thermal stability of the ferromagnetic minerals and their Curie points $\left(T_{\mathrm{c}}\right)$ were estimated from thermomagnetic curves of saturation magnetization $M_{\mathrm{S}}(T)$ obtained with a

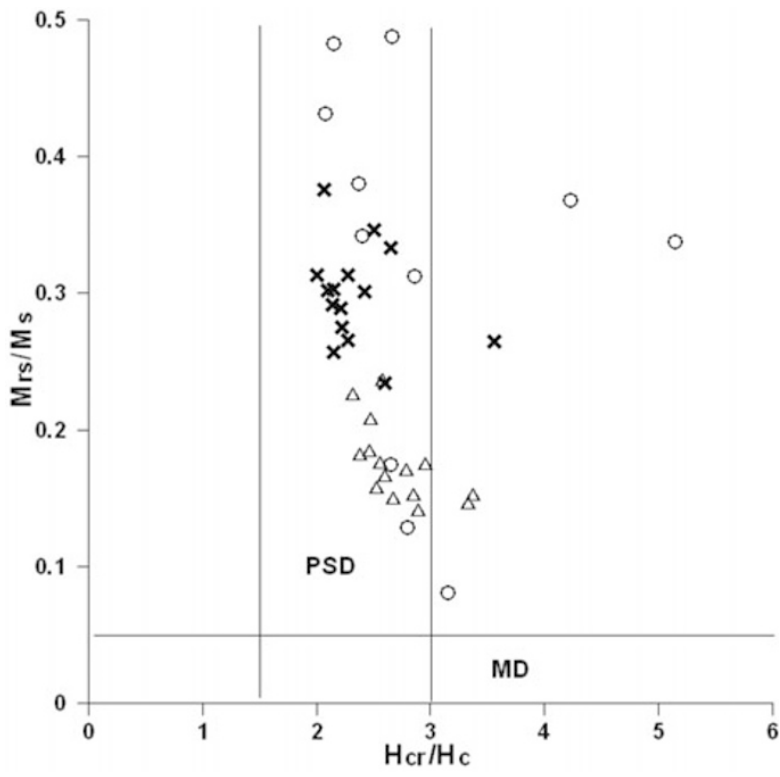

Fig. 4. Day plot for samples from Tovuz $(\bigcirc)$, Paravakar $(\triangle), \operatorname{Kafan}(\times)$ 

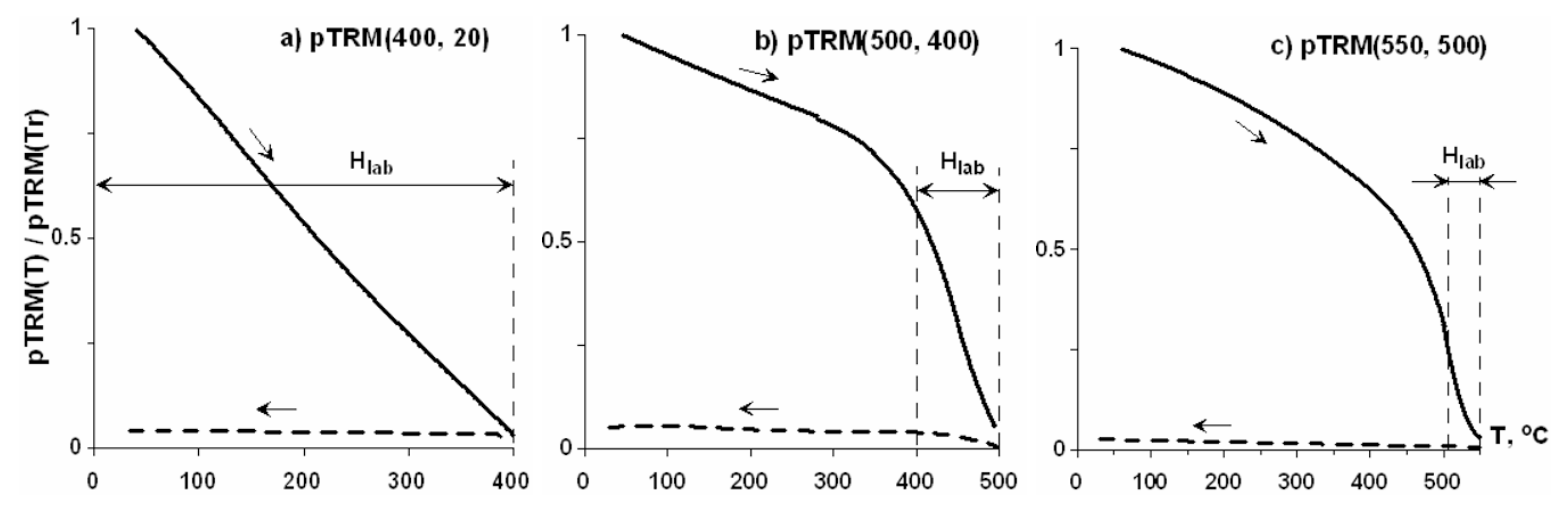

Fig. 5. Paravakar section, sample P124. Application of the thermomagnetic criterion of DS to pTRMs $\left(T_{1}, T_{2}\right),\left(T_{1}>T_{2}\right)$. Vertical lines mark the temperature interval in which pTRM $\left(T_{1}, T_{2}\right)$ was created in a 100- $\mu \mathrm{T}$ field. All curves are measured in zero external field, and values of remanent magnetizations at elevated temperatures are normalized to their values at room temperature $T_{0}$.

Curie balance in an external magnetic field of $450 \mathrm{mT}$, with incremental heating-cooling cycles to higher temperatures $T_{i}=200,300,400,500,600,700^{\circ} \mathrm{C}$. The thermomagnetic curves of saturation remanent magnetization $M_{\mathrm{rs}}(T)$, created in a $1.5 \mathrm{~T}$ field, were also investigated. In this case, two subsequent heating runs to the temperature at which the initial $M_{\mathrm{rs} 0}$ of a particular sample was fully destroyed were carried out, $M_{\mathrm{r} s 0}(T)$ and $M_{\mathrm{rs} 1}(T)$, respectively. These experiments were conducted using the unique full-vector, three-component vibrating sample magnetometer 3D-VSM, designed in the Borok Geophysical Observatory.

The domain structure (DS) of the samples was estimated from the ratios $M_{\mathrm{rs}} / M_{\mathrm{s}}$ and $H_{\mathrm{cr}} / H_{\mathrm{c}}$, where $H_{\mathrm{c}}$ and $H_{\mathrm{cr}}$ are, respectively, the coercive force and the remanent coercive force. The corresponding Day plot (Day et al., 1977) is presented in Fig. 4. As is often the case with natural samples, the ratios $M_{\mathrm{rs}} / M_{\mathrm{s}}$ and $H_{\mathrm{cr}} / H_{\mathrm{c}}$ for all three sections lie mainly within the Pseudo-Single domain (PSD) region, namely, $M_{\mathrm{rs}} / M_{\mathrm{s}}$ ranges from 0.1 to 0.5 and $H_{\mathrm{cr}} / H_{\mathrm{c}} \approx(2-3)$, though a few samples show $H_{\mathrm{cr}} / H_{\mathrm{c}}>3$, which is a characteristic of multidomain (MD) grains.

The thermomagnetic criterion (Shcherbakova et al., 2000) was used at the same time. For that, a partial thermoremanent magnetization $\operatorname{pTRM}\left(T_{1}, T_{2}\right)$ was imparted by cooling a specimen first from $T_{\mathrm{c}}$ to $T_{1}$ in zero field, followed by its cooling in a field from $T_{1}$ to $T_{2}\left(T_{1}>T_{2}\right)$. If $T_{2}$ did not coincide with room temperature $T_{0}$, the specimen was further cooled down to $T_{0}$ in zero fields. By definition, the tail of $\operatorname{pTRM}\left(T_{1}, T_{2}\right)$ is the intensity of the $\operatorname{pTRM}\left(T_{1}, T_{2}\right)$ remaining after its thermal demagnetization by heating to $T_{1}$ and cooling to $T_{0}$ in zero field. The parameter $A\left(T_{1}, T_{0}\right)=\operatorname{tail}\left[\operatorname{TRM}\left(T_{1}, T_{0}\right)\right] / \operatorname{TRM}\left(T_{1}, T_{0}\right)$ is indicative of the DS. According to (Shcherbakov et al., 2001), with an $A\left(300, T_{0}\right)<0.04$, the sample contains predominantly SD grains; the range $0.04<A\left(300, T_{0}\right)<0.15$ corresponds to PSD samples; a really large tail $\left[A\left(300, T_{0}\right)>\right.$ $0.15]$ points to the presence of MD grains.

In total, ten of the 40 samples used for palaeointensity determinations (samples T68, T70, T75, T78, T80 from the Tovuz section; P115, P124 from the Paravakar section, and K229, K248, K251 from the Kafan section) were tested for the thermomagnetic criterion. For this, three pTRMs in temperature intervals $\left(400^{\circ} \mathrm{C}, T_{0}\right),\left(500,400^{\circ} \mathrm{C}\right)$, and $(550$, $500^{\circ} \mathrm{C}$ ) were imparted and then demagnetized by heating to $T_{1}$, followed by cooling to $T_{0}$ in zero field. All of the samples investigated showed a pronounced SD-small PSDlike behavior of pTRMs with very tiny tails, as illustrated in Fig. 5 for the sample P124 of the Paravakar section.

In addition to the Thellier technique, which was the paleointensity method we chose to use, the Wilson's technique was also applied to a number of sister specimens as a selection criterion. Wilson's method has the advantage of being able to quickly assess the degree of similarity between $\operatorname{NRM}(T)$ and $\operatorname{TRM}(T)$, although its application requires a continuous record of magnetic remanence during heating to $T_{\mathrm{c}}$. A fresh sample is initially heated up to $T_{\mathrm{c}}$ in zero field in order to obtain the thermal demagnetization curve $\operatorname{NRM}(T)$. During the subsequent cooling from $T_{\mathrm{c}}$ to room temperature, a known laboratory field $H_{\text {lab }}$ is applied to produce a total $\operatorname{TRM}(T)$ which, in turn, is thermally demagnetized by heating to $T_{\mathrm{c}}$ in zero field. The two thermodemagnetization curves $\operatorname{NRM}(T)$ and $\operatorname{TRM}(T)$ are then compared to determine the temperature interval $\left(T_{\mathrm{w} 1}, T_{\mathrm{w} 2}\right),\left(T_{\mathrm{w} 1}>T_{\mathrm{w} 2}\right)$, at which $\operatorname{NRM}(T)$ is similar to $\operatorname{TRM}(T)$. If such an interval can be found, the ancient field ( $\left.H_{\text {anc }}\right)$ can be estimated from the coefficient of similarity $k_{\mathrm{W}}=\operatorname{NRM}(T) / \operatorname{TRM}(T)=H_{\text {anc }} / H_{\text {lab }}, T \in\left(T_{\mathrm{w} 1}, T_{\mathrm{w} 2}\right)$. But most importantly, the similarity of the $\operatorname{NRM}(T)$ and $\operatorname{TRM}(T)$ curves is usually regarded as a strong argument in favor of a thermoremanent nature of the NRM and, therefore, a primary origin. We rejected samples lacking that similarity from further consideration.

\subsection{Tovuz section}

The magnetic properties of the Tovuz baked contacts are very similar. Thermomagnetic curves $M_{\mathrm{s}}(T)$ only slightly differ from each other, and all show a good thermal stability of the ferrimagnetic minerals. Curie temperatures, which ranged between 600 and $660^{\circ} \mathrm{C}$, indicate the presence of cation-deficient magnetites (Fig. 6(a,d)). The progressive decrease in the intensity of $M_{\mathrm{s}}\left(T_{0}\right)$ with increasing in heat is most likely related to the transformation of maghemite into hematite taking place in some grains (or in part of the grains). However, the degree of the decrease is small, no more than $10-12 \%$ of the total NRM. A few samples, like sample T76 (Fig. 6(d)), show the distinctive occurrence of another ferrimagnetic phase with $T_{\mathrm{c}} \approx 400^{\circ} \mathrm{C}$, evidently ti- 

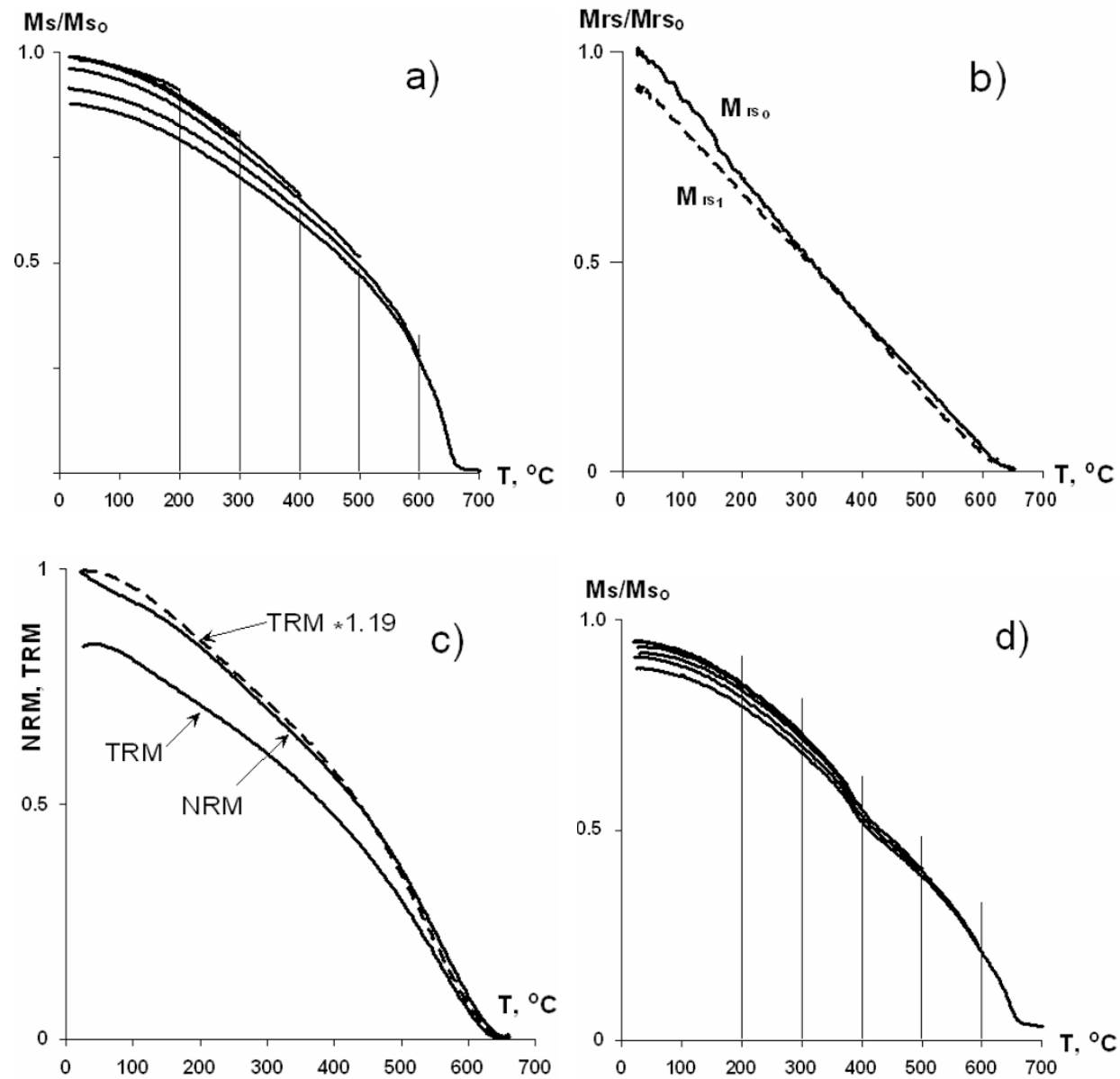

Fig. 6. Tovuz section: (a) Thermomagnetic curves $M_{\mathrm{si}}(T)$ for sample T70 (vertical lines indicate the maximum temperatures $T_{i}$ for each temperature loop); (b) thermodemagnetization curves of saturation remanent magnetization $M_{\mathrm{rs} 0}(T)$ (full line) and $M_{\mathrm{rs} 1}(T)$ (dash line) for sample T70; (c) continuous thermodemagnetization curves of NRM and TRM acquired in $H_{\text {lab }}=20 \mu \mathrm{T}$ (full lines) (dashed line corresponds to the curve TRM* $k_{\mathrm{w}} \cdot \mathrm{TRM}$, in this case $k_{\mathrm{w}}=1.2$; Wilson technique); (d) thermomagnetic curves $M_{\mathrm{si}}(T)$ for sample T76.

tanomagnetite. Thermomagnetic curves $M_{\mathrm{rs}}(T)$ (Fig. 6(b)) also show a good thermal stability, with the exception of a low temperature interval below $300-400^{\circ} \mathrm{C}$ where the initial $M_{\mathrm{rs} 0}(T)$ values are slightly higher than those of the second curve $M_{\mathrm{rs} 1}(T)$. The thermodemagnetization curves $\operatorname{NRM}(T)$ and $\operatorname{TRM}\left(T, H_{\text {lab }}\right)$ are quite similar for most samples in the temperature range $300^{\circ} \mathrm{C}$ to $T_{\mathrm{c}}$, favoring the thermoremanent nature of the NRM-at least for this high temperature interval. In some samples, the similarity persists for the whole temperature range, as in the case of sample 70 (Fig. 6(c)). Curie temperatures estimated from the $M_{\mathrm{rs}}(T)$ and $\operatorname{NRM}(T)$ thermodemagnetization curves agree well with those determined from the $M_{\mathrm{S}}(T)$ curves, thereby confirming cation-deficient magnetite as the main carrier of the magnetic remanence.

\subsection{Paravakar section}

A rock magnetic analysis was carried out only on samples from Paravakar site P1, which passed the paleointensity selection criteria. Typical thermodemagnetization curves $M_{\mathrm{si}}(T), M_{\mathrm{rs} 0}(T)$, and $M_{\mathrm{rs} 1}(T)$ show that the Paravakar samples are usually not as thermally stable as the Tovuz samples, indicating the occurrence of significant mineralogical changes during laboratory heatings (Fig. 7(a,b)). The sharp decrease in the $M_{\mathrm{s}}(T)$ and $M_{\mathrm{rs}}(T)$ curves on these graphs most likely reflects the maghemite-hematite transition. Fol- lowing these changes, high Curie temperatures ranging between 580 and $600^{\circ} \mathrm{C}$ indicate the presence of magnetite in the rocks (Fig. 7(a)). The presence of abundant primary magnetite (maghemite?) grains in the Paravakar samples is confirmed by direct electron microscopic observations. Despite the mineralogical changes, the thermodemagnetization curves $\operatorname{NRM}(T)$ and $\operatorname{TRM}(T)$ are similar over a wide temperature interval (Fig. 7(c)), suggesting that the mineralogical changes primarily affect coarse grains, which have a fairly small contribution to the NRM and TRM intensities, while the main carriers are composed of a mixture of SD-PSD grains which either are not sensitive to the thermal alteration or have already been altered in the natural environment at $T>T_{\mathrm{c}}$ before or during the baking of the sediments by the overlying lava. This suggestion is supported as well by the results of the hysteresis parameters measurements (mean $M_{\mathrm{rs}} / M_{\mathrm{s}}=0.18$, mean $H_{\mathrm{cr}} / H_{\mathrm{c}}=2.74$ typical for PSD grain sizes) and by the pTRM tails of the thermomagnetic criterion (Shcherbakova et al., 2000; Shcherbakov et al., 2001). Indeed, as seen in Fig. 5, all three measured pTRMs show very tiny tails. According to that criterion, this would indicate pure SD behavior of the remanence carriers. However, this conclusion has to be taken with caution as the thermomagnetic criterion implies preliminary heating of the specimen to $T_{\mathrm{c}}$, and we know that the heating of Par- 

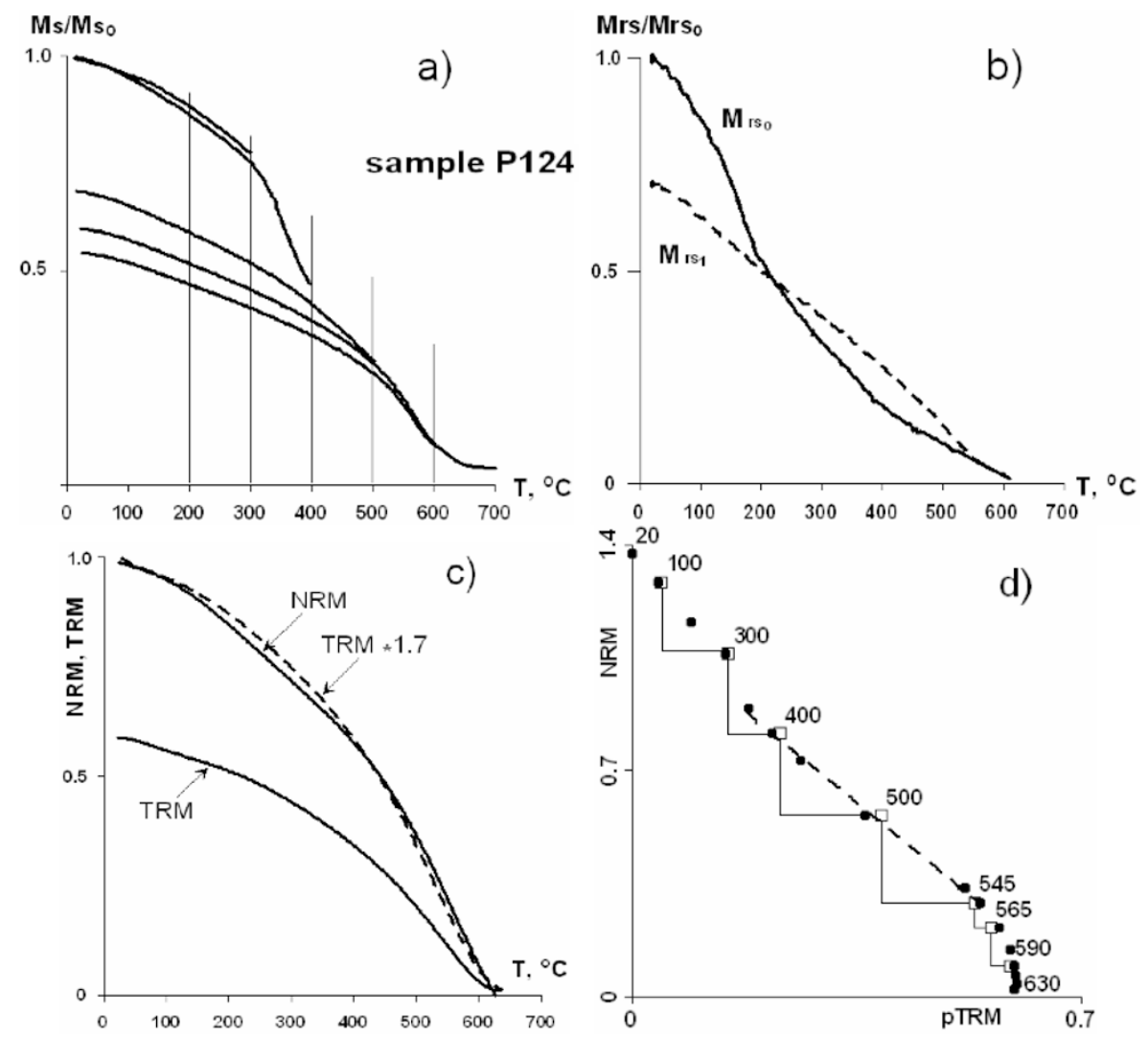

Fig. 7. Paravakar section, sample P124: (a), (b), and (c) notations as in Fig. 6; (d) Arai-Nagata plot.

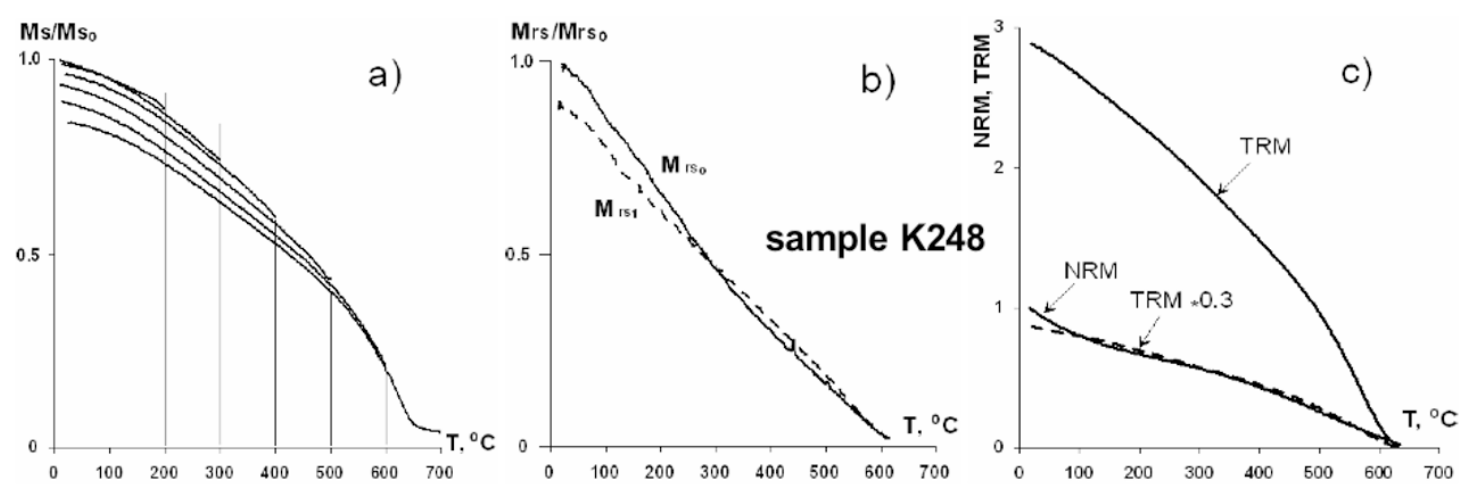

Fig. 8. Kafan section, sample K248. (a), (b), and (c) notations as in Fig. 6.

avakar samples produces noticeable mineralogical changes (Fig. 7(a, b)). The result of the thermomagnetic criterion shows that the TRM formed after heating to $T_{\mathrm{c}}$ is carried by SD grains. Considering also the pretty good similarity between the thermodemagnetizing curves of NRM and total TRM (Fig. 7(c)), one may suggest that the NRM carriers might be dominated by SD grains. In addition, no particular behavior can be seen on the Arai-Nagata diagrams in the vicinity of $300-400^{\circ} \mathrm{C}$, and the pTRM checks up to $500^{\circ} \mathrm{C}$ (empty squares; Fig. 7(d)) lie close to the corresponding pTRMs points (full squares; Fig. 7(d)). This fact also supports the validity of paleointensity determinations obtained on this section. Note also that a few thermodemagnetization curves $M_{\mathrm{si}}(T)$ of the Paravakar samples display a ferrimag- netic phase with $T_{\mathrm{c}} \approx 400^{\circ} \mathrm{C}$ similar to the one observed in some Tovuz samples.

\subsection{Kafan section}

The thermal stability of these rocks is evidenced by the reversibility of the thermomagnetic curves $M_{\mathrm{S}}(T)$ and $M_{\mathrm{rs}}(T)$ (Fig. 8(a, b)). However, the Curie temperatures that can be estimated are much higher on average than those from the Tovuz section and range between 630 and $660^{\circ} \mathrm{C}$. This difference is likely to be due to a higher oxidation state of the Kafan rocks. The thermodemagnetization curves $\operatorname{NRM}(T)$ and $\operatorname{TRM}(T)$ are quite similar for most samples in the temperature range $300^{\circ} \mathrm{C}$ to $T_{\mathrm{c}}$ (Fig. 8(c)), favoring the thermoremanent nature of the NRM at least for this temperature interval. The presence of two mag- 


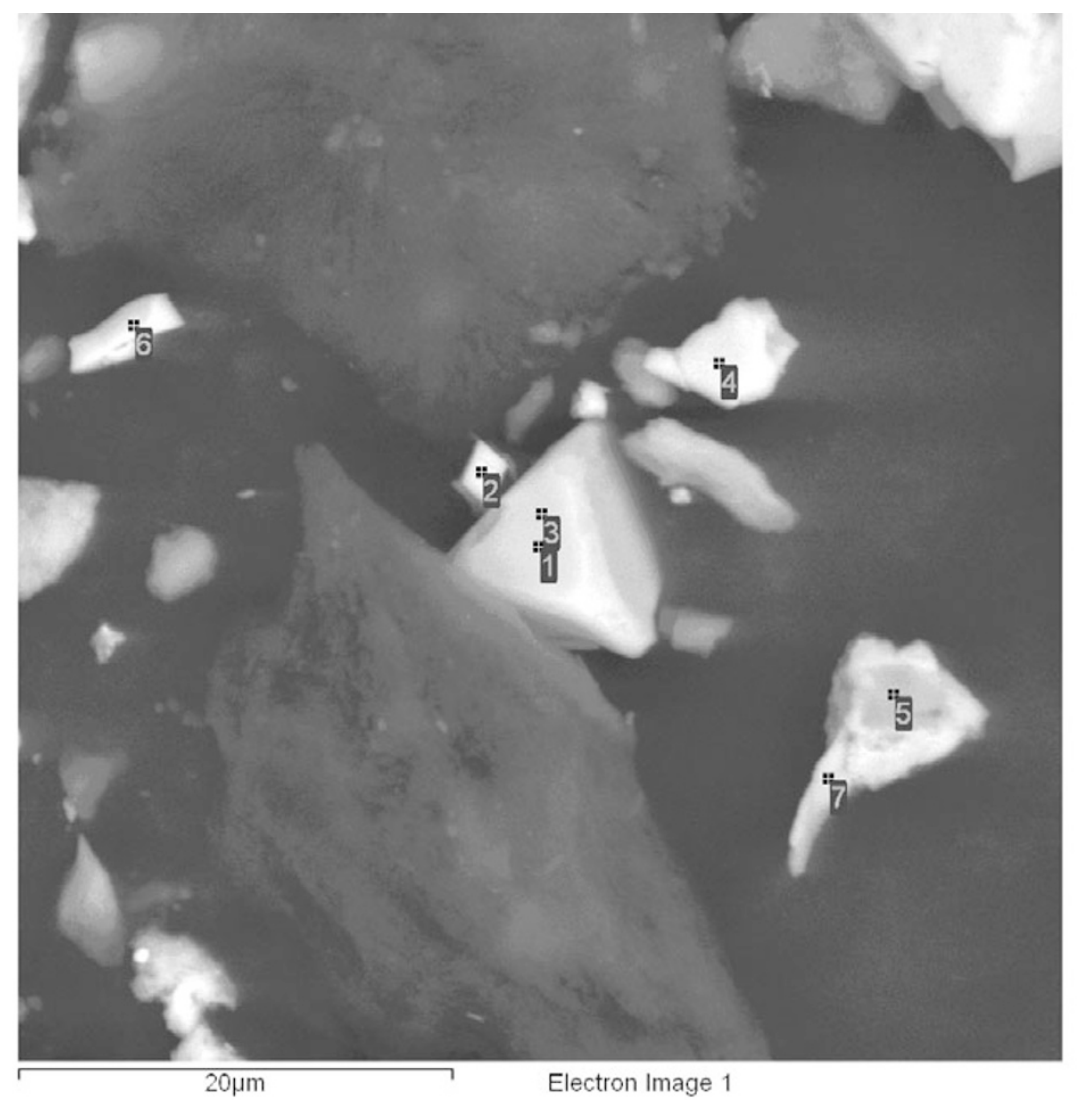

Fig. 9. SEM backscattering image of magnetic grains extracted from sample K228, Kafan section.

netic phases was also detected on some samples, suggesting the coexistence in the samples of both magnetite and titanomagnetite phases, which is supported by direct electron microscopic observations. A typical example of electron micrograph taken on sample 228 from the Kafan section is shown on Fig. 9. Energy dispersive X-ray (EDX) analysis shows that the fine grains (labeled 2, 4 and 6 on Fig. 9) contain only iron and oxygen with a very low percentage of $\mathrm{Mg}$ and Al. Therefore, these grains, $2-5 \mu \mathrm{m}$ in size, belong to the magnetite-maghemite series. On the other hand, coarser grains (labeled 1 and 5, Fig. 9) contain a significant amount of titanium; more precisely, according to the EDX analysis, these grains can be described by the formula $\mathrm{Ti}_{x} \mathrm{Fe}_{3-x} \mathrm{O}_{4}$ with $x \approx 0.25$, corresponding to titanomagnetite with $T_{\mathrm{c}} \approx$ $400^{\circ} \mathrm{C}$.

In summary, the rock magnetic properties of the studied sections point to cation-deficient SD-PSD magnetite grains, with $T_{\mathrm{c}}$ ranging from 600 to $660^{\circ} \mathrm{C}$, as the main carrier of the magnetic remanence.

This observation may cast doubts on the thermoremanent nature of the NRM as samples may undergo maghemitization due to their baking in situ or later during the laboratory experiments. Fortunately, this single-phase oxidation does not affect substantially the magnetic state and magnetic properties of a grain - at least for SD and small PSD grains (Dunlop and Ozdemir, 1997). Therefore, a lowtemperature oxidation has little effect on the fine fraction of ferrimagnetic minerals, and no change in the direction of the initial remanence was observed when SD magnetite was oxidized to maghemite (Johnson and Merrill, 1973).
The same reasoning can be applied to the problem of paleointensity determinations, as far as the fine grain fraction is concerned.

However, the possibility that the remanence stored in oxidized rocks might be a TCRM instead of a TRM (Smirnov and Tarduno, 2005) should be discussed. Indeed, if TRM and TCRM have a similar thermal stability, i.e. similar blocking temperature $\left(T_{\mathrm{b}}\right)$ spectrum, they will be undistinguishable from the point of view of Thellier experiments, eventually bringing about false results. However, no firm experimental or theoretical evidence supports such a similar thermal stability of TRM and TCRM. To the contrary, "from theory, it follows that TCRM and TRM intensities should differ" (Smirnov and Tarduno, 2005). Indeed, the only developed theoretical scheme for TCRM acquisition is the grain growth mechanism of acquisition of the crystallization remanent magnetization (CRM) proposed by Kobayashi (1962). It was subsequently shown by Stacey and Banerjee (1974) that, for non-interacting SD grains, the relation CRM/TRM $=H_{\mathrm{K}}\left(T_{\mathrm{b}}\right) / H_{\mathrm{K}}\left(T_{\mathrm{CRM}}\right)<1$, where $T_{\mathrm{CRM}}$ is the temperature of the CRM acquisition, and $H_{\mathrm{K}}$ is the coercive force of a grain. Thus, the CRM/TRM relation is a function of $T_{\mathrm{b}}$ and $T_{\mathrm{CRM}}$, which means that their blocking temperature spectra are not identical. This conclusion was confirmed later by numerical Monte-Carlo modeling of TRM and CRM acquisition carried out by Shcherbakov et al. (1996) who showed, in particular, that for strong magnetostatic interaction-i.e., in the case of a high volume concentration of SD grains - the relation CRM/TRM $<1$, valid for non-interacting SD grains, reverses to CRM/TRM 
a) sample T70
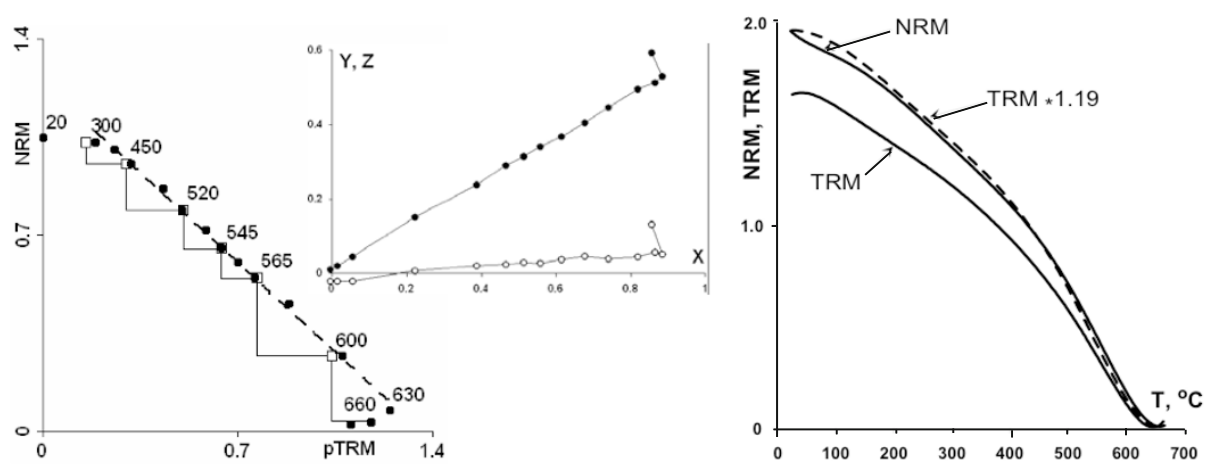

b) sample P121
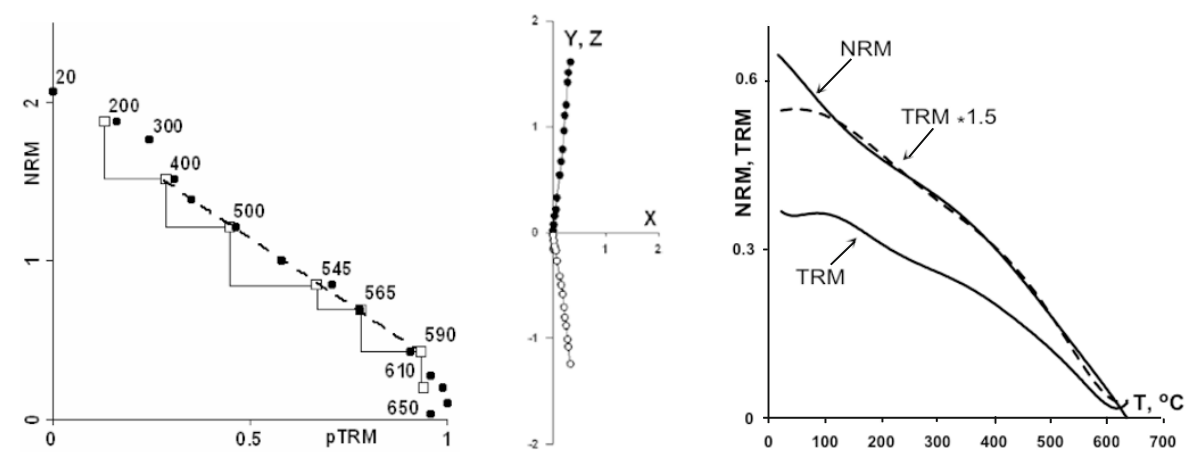

c) sample K230
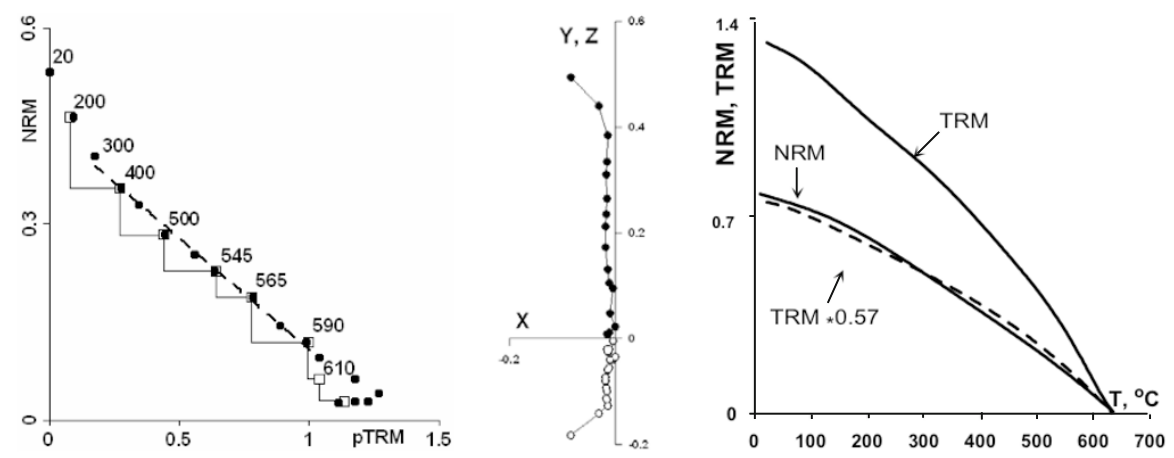

Fig. 10. Representative examples of accepted palaeointensity results for samples (a) T70, Tovuz section, (b) P121, Paravakar section, (c) K230, Kafan 1 section, (d) K248, Kafan 2 section, and (e) K281, Kafan 3 section: Arai-Nagata plots (left), corresponding orthogonal plots (middle, core coordinates), and continuous thermodemagnetization curves of NRM and TRM (full lines) acquired in $H_{\text {lab }}=20 \mu \mathrm{T}$ (right, Wilson technique; dashed line corresponds to the curve TRM $* k_{\mathrm{w}}$.TRM, in these cases $k_{\mathrm{w}}$ are equal to $1.19,1.5,0.57,0.3,0.855$ for the samples T70, P121, K230, K248, K281, respectively. Intensity of magnetization is given in $\mathrm{A} / \mathrm{m}$ ).

$>1$. Still, the thermal stability of TCRM and TRM can be compared for a narrow temperature range, so one must be cautious interpreting results obtained on samples having a narrow $T_{\mathrm{b}}$ spectrum. However, the samples from the collection under study show similar NRM and TRM observed on a rather wide interval of blocking temperatures extending from $\approx 300^{\circ} \mathrm{C}$ to $T_{\mathrm{c}}$ (Figs. 6(c), 7(c), 8(c) and 10(a-e), right diagrams).

From the experimental side, controversial data on the similarity of alternating field and thermal responses of TRM and CRM have been reported (Dunlop and Ozdemir, 1997). Moreover, the only direct Thellier experiments with TCRM and TRM that have been published in the literature and performed on SD maghemite grains precipitated in lepidocrocite grains showed a drastic non-similarity of the AraiNagata diagrams of these two remanences (Gendler et al., 2005). Thus, we conclude that the strong similarity of the NRM-TRM plots and the good quality of the Arai-Nagata 
d) sample $\mathrm{K} 248$
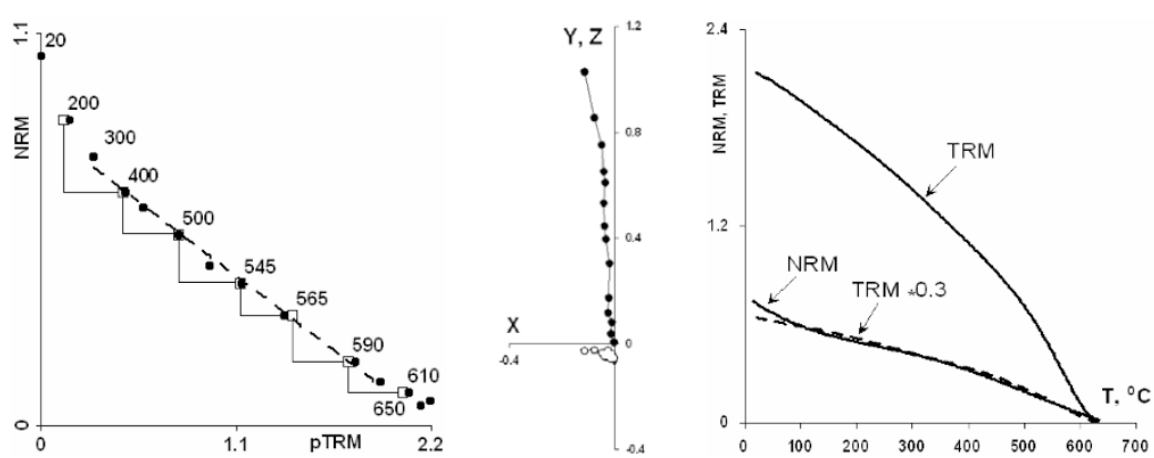

e) sample K281
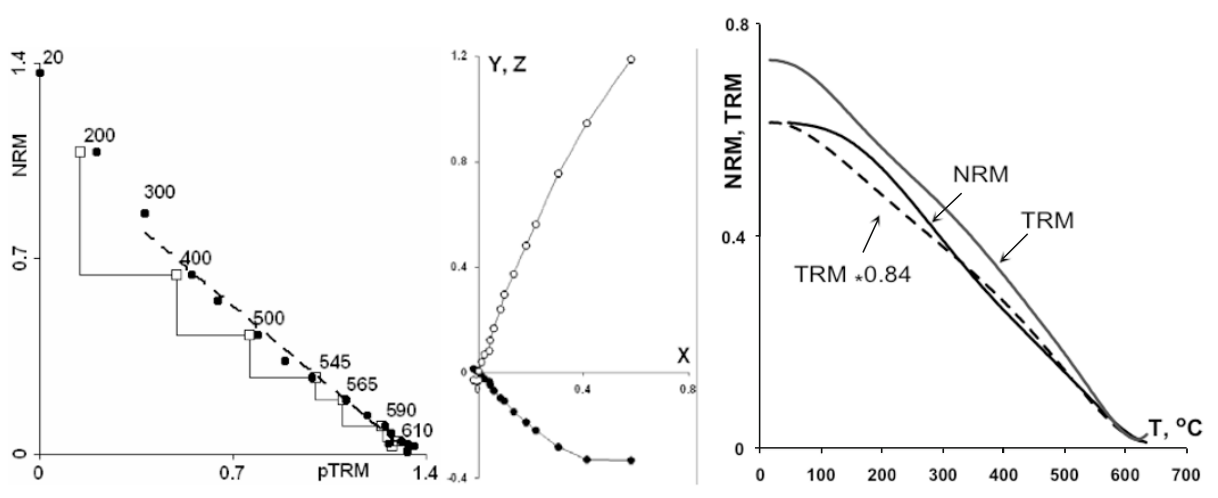

Fig. 10. (continued).

plots observed on a wide temperature interval, together with the lack of significant chemical and structural alterations under thermal treatment found in a majority of samples (Figs. 6(a, b), 8(a, b)), provide evidence in favor of a TRM origin for the NRM of these samples.

\section{Paleointensity Experiments and Results}

Palaeointensity determinations were performed using the Coe-modified Thellier method (Coe, 1967). The experiments consisted of double heatings in air to a set of increasing temperatures $T_{i}, i=1 . . n$. The first heating-cooling step to $T_{i}$ took place in zero field, and the second heating was also performed in a nonmagnetic space but was followed by cooling in a known laboratory field $H_{\text {lab }}=20 \mu \mathrm{T}$. This value was chosen deliberately because test experiments indicated quite low palaeointensities around 10-20 $\mu \mathrm{T}$, and it has been demonstrated that experimental errors are minimized when the ancient and laboratory fields are close to each other. Double heatings were carried out in at least 16 steps up to $650^{\circ} \mathrm{C}$, and pTRM checks and susceptibility measurements were performed after every second step. For each sample, two to four cubic specimens, $1 \mathrm{~cm}$ in size, were used for palaeointensity determinations. Some of the specimens were heated in an electric furnace with a residual field $<50 \mathrm{nT}$, while the others were treated in the threecomponent vibrating sample magnetometer 3D-VSM. For specimens heated in the electric furnace, magnetic measurements were made using a fully computerized astatic mag- netometer having a sensitivity of $10^{-9} \mathrm{~A} \mathrm{~m}^{2}$. The 3D-VSM performs a completely automated Thellier procedure, and the results are recorded on a master computer that enables experiments on different samples to be carried out under exactly the same algorithm, thus minimizing experimental errors. The sensitivity of the 3D-VSM is $10^{-8} \mathrm{~A} \mathrm{~m}^{2}$, and the maximum external field which can be applied along the vertical axis is $0.2 \mathrm{mT}$.

As mentioned above, the Wilson's method of palaeointensity determinations was also applied to a number of sister specimens to test the thermoremanent nature of NRM and compare $H_{\text {anc }}$ determinations obtained by the two techniques.

To analyze palaeointensity data, we constructed AraiNagata diagrams and orthogonal plots for each sample. The palaeointensity result for a sample was accepted only if it satisfied the following set of selection criteria:

- The existence of a wide enough temperature interval (not less than the temperature interval used for the linear fit on the Arai-Nagata diagram) over which the curves $\operatorname{NRM}(T)$ and $\operatorname{TRM}(T)$ are similar (positive outcome of the Wilson's method).

- The linear fit on the Arai-Nagata diagram used for palaeointensity determination should contain at least four consecutive data points over a temperature inter$\operatorname{val}\left(T_{1}, T_{2}\right),\left(T_{1}>T_{2}\right)$.

- The NRM vector is univectorial through the temperature range $\left(T_{1}, T_{2}\right)$ used for paleointensity determina- 
Table 2. Palaeointensity results. $N_{p}$ is the number of successive data points in the temperature interval $\left(T_{1}, T_{2}\right)$ used for the calculation of $H_{\text {anc }}$.

\begin{tabular}{|c|c|c|c|c|c|c|c|c|c|}
\hline Specimen & $T_{1}-T_{2}$ & $N_{p}$ & $g$ & $q$ & $f$ & $k$ & $H_{\text {anc }} \mu \mathrm{T}$ & $\sigma$ & $H_{\text {anc }} \mu \mathrm{T}$ \\
\hline \multicolumn{10}{|c|}{ Tovuz-6 } \\
\hline T66 & $300-580$ & 10 & 0.88 & 7.25 & 0.42 & 1.31 & 26.2 & 1.8 & 20 \\
\hline T66-2 & $450-630$ & 10 & 0.87 & 11.73 & 0.49 & 0.96 & 19.2 & 0.7 & 24 \\
\hline T66а & $400-630$ & 11 & 0.88 & 14.41 & 0.64 & 1.06 & 21.2 & 0.9 & \\
\hline T67 & $400-630$ & 11 & 0.88 & 12.51 & 0.59 & 1.13 & 22.7 & 1.0 & 26 \\
\hline $\mathrm{T} 67 \mathrm{a}$ & $300-580$ & 10 & 0.82 & 6.56 & 0.58 & 0.92 & 18.5 & 1.2 & 20 \\
\hline T68 & $300-630$ & 12 & 0.89 & 20.56 & 0.66 & 1. & 20.0 & 0.6 & 18 \\
\hline T68a & $300-630$ & 12 & 0.86 & 13.41 & 0.71 & 1.05 & 21.0 & 1.0 & 20 \\
\hline T69 & $500-630$ & 9 & 0.75 & 31.54 & 0.83 & 0.75 & 15.0 & 0.2 & 17 \\
\hline T69a & $400-630$ & 11 & 0.88 & 5.79 & 0.44 & 0.8 & 15.9 & 0.9 & \\
\hline $\mathrm{T} 70$ & $300-630$ & 12 & 0.88 & 43.32 & 0.91 & 0.92 & 18.3 & 0.3 & 23.8 \\
\hline $\mathrm{T} 70 \mathrm{a}$ & $300-630$ & 12 & 0.85 & 22.21 & 0.83 & 0.92 & 18.4 & 0.5 & \\
\hline $\mathrm{T} 71$ & $400-630$ & 11 & 0.89 & 37.93 & 0.65 & 0.91 & 18.2 & 0.3 & 22 \\
\hline T71a & $400-660$ & 12 & 0.88 & 8.42 & 0.62 & 0.87 & 17.3 & 1.0 & \\
\hline T72 & $400-630$ & 11 & 0.83 & 69.75 & 0.81 & 1.03 & 20.6 & 0.2 & 13.1 \\
\hline T72-2 & $400-660$ & 12 & 0.87 & 20.2 & 0.89 & 0.82 & 16.5 & 0.5 & 12 \\
\hline $\mathrm{T} 72 \mathrm{a}$ & $400-630$ & 11 & 0.87 & 19.2 & 0.77 & 0.87 & 17.3 & 0.5 & \\
\hline $\mathrm{T} 73$ & $300-630$ & 12 & 0.89 & 9.22 & 0.66 & 0.88 & 17.7 & 1.0 & 16.4 \\
\hline T73-2 & $400-630$ & 11 & 0.88 & 28.0 & 0.74 & 0.88 & 17.7 & 0.4 & \\
\hline $\mathrm{T} 74$ & $520-630$ & 8 & 0.79 & 13.97 & 0.56 & 1.0 & 20.0 & 0.7 & 22 \\
\hline $\mathrm{T} 74 \mathrm{a}$ & $400-630$ & 11 & 0.86 & 18.58 & 0.85 & 0.96 & 19.1 & 0.7 & 16.4 \\
\hline $\mathrm{T} 75$ & $300-630$ & 12 & 0.87 & 60.95 & 0.94 & 1.09 & 21.8 & 0.3 & 21.4 \\
\hline T75-2 & $20-630$ & 13 & 0.89 & 105.81 & 0.98 & 1.0 & 19.9 & 0.2 & \\
\hline T75a & $20-630$ & 13 & 0.9 & 28.51 & 0.97 & 1.02 & 20.3 & 0.6 & \\
\hline T76 & $300-630$ & 12 & 0.86 & 24.97 & 0.72 & 1.36 & 27.2 & 0.9 & 30 \\
\hline T77 & $300-630$ & 13 & 0.9 & 18.74 & 0.78 & 1.21 & 24.2 & 1.1 & 27 \\
\hline $\mathrm{T} 77-2$ & $300-630$ & 13 & 0.9 & 35.47 & 0.84 & 1.01 & 20.3 & 0.4 & \\
\hline $\mathrm{T} 77 \mathrm{a}$ & $300-660$ & 13 & 0.85 & 11.3 & 0.88 & 1.32 & 26.3 & 2.3 & \\
\hline T78 & $300-630$ & 13 & 0.9 & 31.18 & 0.86 & 1.09 & 21.7 & 0.6 & 28 \\
\hline $\mathrm{T} 78 \mathrm{a}$ & $300-610$ & 11 & 0.88 & 20.9 & 0.75 & 0.95 & 18.9 & 0.6 & \\
\hline T79 & $300-660$ & 14 & 0.9 & 45.75 & 0.98 & 1.28 & 25.5 & 0.6 & 22 \\
\hline T79a & $300-600$ & 10 & 0.84 & 9.94 & 0.68 & 1.04 & 20.7 & 1.2 & \\
\hline T80 & $300-630$ & 13 & 0.87 & 44.26 & 0.84 & 1.22 & 24.5 & 0.5 & 22 \\
\hline T80a & $200-630$ & 13 & 0.89 & 23.08 & 0.86 & 1.09 & 21.7 & 0.8 & \\
\hline T81 & $300-630$ & 12 & 0.88 & 58.22 & 0.85 & 1.0 & 20.1 & 0.3 & 22 \\
\hline T82 & $300-630$ & 13 & 0.91 & 34.01 & 0.75 & 0.97 & 19.5 & 0.4 & 26 \\
\hline $\mathrm{T} 82 \mathrm{a}$ & $300-630$ & 12 & 0.89 & 19.17 & 0.72 & 0.81 & 16.1 & 0.4 & \\
\hline \multicolumn{10}{|c|}{ Paravakar-1 } \\
\hline P106 & $350-580$ & 8 & 0.85 & 11.31 & 0.64 & 1.2 & 24.0 & 1.4 & 39 \\
\hline P106a & $400-650$ & 10 & 0.86 & 5.43 & 0.45 & 1.29 & 25.8 & 2.4 & \\
\hline P107a & $300-580$ & 7 & 0.77 & 4.36 & 0.58 & 1.48 & 29.5 & 4.5 & 32 \\
\hline P108 & $300-590$ & 8 & 0.82 & 4.07 & 0.44 & 1.71 & 34.2 & 5.3 & 36.8 \\
\hline P109 & $400-600$ & 8 & 0.84 & 8.44 & 0.47 & 1.26 & 25.3 & 1.5 & 41 \\
\hline P109a & $400-610$ & 8 & 0.78 & 4.57 & 0.47 & 1.31 & 26.2 & 2.8 & \\
\hline $\mathrm{P} 113$ & $400-610$ & 10 & 0.84 & 5.3 & 0.39 & 1.16 & 23.2 & 1.7 & 22 \\
\hline P114 & $400-590$ & 7 & 0.83 & 5.81 & 0.35 & 1.34 & 26.9 & 1.8 & 27 \\
\hline P114a & $400-580$ & 8 & 0.85 & 5.16 & 0.32 & 1.2 & 24.0 & 1.5 & \\
\hline P115 & $400-600$ & 8 & 0.85 & 4.94 & 0.3 & 1.18 & 24.0 & 1.4 & 42 \\
\hline P115a & $400-595$ & 9 & 0.84 & 6.24 & 0.41 & 1.34 & 26.8 & 2.0 & \\
\hline P116 & $400-590$ & 7 & 0.81 & 7.35 & 0.43 & 0.92 & 18.4 & 0.8 & 22 \\
\hline P117 & $300-610$ & 10 & 0.87 & 10.15 & 0.56 & 1.38 & 27.7 & 1.8 & 24 \\
\hline P117a & $400-590$ & 8 & 0.85 & 8.36 & 0.46 & 1.03 & 20.7 & 1.0 & \\
\hline P118-2 & $200-600$ & 12 & 0.9 & 7.74 & 0.61 & 1.47 & 29.3 & 3.1 & 24 \\
\hline P119 & $400-630$ & 10 & 0.87 & 16.82 & 0.62 & 1.2 & 24.0 & 0.9 & 31 \\
\hline $\mathrm{P} 120$ & $300-565$ & 7 & 0.84 & 6.28 & 0.38 & 1.57 & 31.5 & 2.5 & \\
\hline $\mathrm{P} 121$ & $400-590$ & 7 & 0.83 & 12.38 & 0.53 & 1.73 & 34.6 & 2.1 & 30 \\
\hline P121a & $300-620$ & 11 & 0.85 & 6.76 & 0.65 & 1.63 & 32.7 & 4.4 & \\
\hline $\mathrm{P} 123$ & $200-530$ & 7 & 0.81 & 7.51 & 0.47 & 1.22 & 24.4 & 1.5 & 33 \\
\hline P123a & $300-610$ & 11 & 0.85 & 6.18 & 0.51 & 1.17 & 23.7 & 2.0 & \\
\hline $\mathrm{P} 124 \mathrm{a}$ & $400-595$ & 9 & 0.87 & 7.62 & 0.51 & 1.47 & 29.3 & 2.5 & 34 \\
\hline P124-2 & $350-565$ & 7 & 0.78 & 16.2 & 0.5 & 1.66 & 33.2 & 1.3 & \\
\hline
\end{tabular}


Table 2. (continued).

\begin{tabular}{|c|c|c|c|c|c|c|c|c|c|}
\hline Specimen & $T_{1}-T_{2}$ & $N_{p}$ & $g$ & $q$ & $f$ & $k$ & $H_{\text {anc }} \mu \mathrm{T}$ & $\sigma$ & $H_{\text {anc }} \mu \mathrm{T}$ \\
\hline \multicolumn{10}{|c|}{ Kafan-1 } \\
\hline K226-2a & $500-575$ & 6 & 0.72 & 9.44 & 0.47 & 0.77 & 15.326 & 0.4 & \\
\hline K228 & $200-600$ & 11 & 0.89 & 24.63 & 0.74 & 0.59 & 11.856 & 0.2 & 12 \\
\hline $\mathrm{K} 228 \mathrm{a}$ & $400-600$ & 10 & 0.86 & 7.55 & 0.58 & 0.41 & 8.161 & 0.2 & \\
\hline K229 & $200-600$ & 11 & 0.89 & 18.27 & 0.81 & 0.65 & 13.079 & 0.3 & 13.2 \\
\hline K229a & $300-600$ & 11 & 0.88 & 11.83 & 0.62 & 0.57 & 11.453 & 0.3 & \\
\hline K230 & $300-600$ & 10 & 0.88 & 18.79 & 0.58 & 0.34 & 6.86 & 0.1 & 11.4 \\
\hline $\mathrm{K} 230 \mathrm{a}$ & $300-630$ & 12 & 0.89 & 11.75 & 0.6 & 0.37 & 7.36 & 0.1 & \\
\hline $\mathrm{K} 231$ & $300-610$ & 11 & 0.81 & 16.12 & 0.76 & 0.58 & 11.614 & 0.3 & 11.6 \\
\hline K231a & $300-610$ & 11 & 0.88 & 27.65 & 0.68 & 0.4 & 8.04 & 0.1 & \\
\hline K232 & $400-610$ & 10 & 0.87 & 32.12 & 0.58 & 0.41 & 8.28 & 0.1 & 9.6 \\
\hline $\mathrm{K} 232 \mathrm{a}$ & $400-590$ & 8 & 0.84 & 10.46 & 0.45 & 0.41 & 8.22 & 0.1 & \\
\hline K233 & $300-610$ & 10 & 0.87 & 34.6 & 0.77 & 0.58 & 11.524 & 0.1 & 11 \\
\hline $\mathrm{K} 233 \mathrm{a}$ & $300-575$ & 9 & 0.82 & 4.38 & 0.5 & 0.71 & 14.244 & 0.9 & 12 \\
\hline K234 & $300-610$ & 11 & 0.9 & 38.6 & 0.74 & 0.54 & 10.854 & 0.1 & 10.4 \\
\hline $\mathrm{K} 234 \mathrm{a}$ & $200-580$ & 9 & 0.84 & 6.36 & 0.59 & 0.45 & 8.5 & 0.3 & \\
\hline K235 & $300-610$ & 11 & 0.89 & 35.77 & 0.67 & 0.53 & 10.65 & 0.1 & 12.2 \\
\hline $\mathrm{K} 235 \mathrm{a}$ & $300-610$ & 11 & 0.88 & 29.69 & 0.82 & 0.43 & 8.5 & 0.1 & \\
\hline K236-2 & $400-590$ & 8 & 0.83 & 33.14 & 0.54 & 0.29 & 5.84 & 0.0 & 4.4 \\
\hline K236a & $400-610$ & 10 & 0.84 & 13.85 & 0.57 & 0.22 & 4.34 & 0.0 & \\
\hline $\mathrm{K} 237 \mathrm{a}$ & $400-650$ & 12 & 0.86 & 11.16 & 0.64 & 0.48 & 9.52 & 0.2 & 12.8 \\
\hline $\mathrm{K} 238 \mathrm{a}$ & $400-610$ & 10 & 0.87 & 7.36 & 0.58 & 0.49 & 9.73 & 0.3 & 12.4 \\
\hline K239 & $300-630$ & 12 & 0.91 & 44.12 & 0.85 & 0.5 & 9.93 & 0.1 & 12.2 \\
\hline K239a & $200-595$ & 11 & 0.88 & 14.51 & 0.63 & 0.57 & 11.448 & 0.2 & \\
\hline K240a & $300-595$ & 10 & 0.88 & 17.26 & 0.61 & 0.54 & 10.885 & 0.2 & 10 \\
\hline K243 & $300-610$ & 11 & 0.9 & 34.98 & 0.74 & 0.44 & 8.755 & 0.1 & \\
\hline K244a & $300-595$ & 10 & 0.88 & 9.53 & 0.61 & 0.52 & 10.486 & 0.3 & 12 \\
\hline K245 & $200-610$ & 12 & 0.89 & 40.51 & 0.87 & 0.58 & 11.683 & 0.1 & \\
\hline $\mathrm{K} 245 \mathrm{a}$ & $300-630$ & 11 & 0.88 & 20.68 & 0.76 & 0.55 & 10.967 & 0.2 & \\
\hline $\mathrm{K} 246-2 \mathrm{a}$ & $200-600$ & 11 & 0.89 & 17.16 & 0.77 & 0.62 & 12.403 & 0.3 & 13.2 \\
\hline K246a & $200-630$ & 12 & 0.9 & 17.05 & 0.82 & 0.64 & 12.749 & 0.4 & \\
\hline $\mathrm{K} 247 \mathrm{a}$ & $200-620$ & 12 & 0.9 & 27.3 & 0.86 & 0.52 & 10.312 & 0.1 & 12.2 \\
\hline \multicolumn{10}{|c|}{ Kafan-2 } \\
\hline K248 & $300-600$ & 9 & 0.86 & 18.12 & 0.61 & 0.38 & 7.58 & 0.1 & 6 \\
\hline K248a & $300-600$ & 10 & 0.84 & 15.38 & 0.61 & 0.3 & 5.93 & 0.1 & \\
\hline $\mathrm{K} 250$ & $300-610$ & 11 & 0.86 & 10.61 & 0.38 & 0.2 & 5.96 & 0.1 & \\
\hline K251 & $300-580$ & 8 & 0.8 & 6.09 & 0.41 & 0.46 & 9.15 & 0.2 & 7.2 \\
\hline K251a & $200-600$ & 11 & 0.79 & 6.13 & 0.53 & 0.37 & 7.36 & 0.2 & \\
\hline K252 & $300-600$ & 10 & 0.88 & 19.67 & 0.64 & 0.35 & 6.96 & 0.1 & 8 \\
\hline K253 & $20-545$ & 8 & 0.77 & 28.87 & 0.78 & 0.46 & 9.25 & 0.1 & 8 \\
\hline K253a & $300-580$ & 8 & 0.83 & 4.43 & 0.5 & 0.36 & 7.29 & 0.2 & \\
\hline $\mathrm{K} 254$ & $300-580$ & 8 & 0.84 & 9.49 & 0.41 & 0.31 & 6.17 & 0.1 & 7 \\
\hline $\mathrm{K} 255$ & $300-590$ & 9 & 0.86 & 13.1 & 0.5 & 0.34 & 6.81 & 0.1 & 8 \\
\hline K256 & $300-610$ & 11 & 0.89 & 15.27 & 0.61 & 0.27 & 5.48 & 0.1 & 5.6 \\
\hline K257 & $450-600$ & 9 & 0.85 & 12.93 & 0.43 & 0.27 & 5.39 & 0.0 & 8.4 \\
\hline K257-2 & $350-580$ & 9 & 0.87 & 11.07 & 0.51 & 0.32 & 6.39 & 0.1 & \\
\hline K264 & $400-630$ & 10 & 0.87 & 11.04 & 0.42 & 0.45 & 8.71 & 0.1 & 9.8 \\
\hline \multicolumn{10}{|c|}{ Kafan-3 } \\
\hline K267 & $200-630$ & 13 & 0.9 & 15.18 & 0.86 & 1.0 & 19.986 & 1.0 & 20 \\
\hline $\mathrm{K} 270$ & $200-630$ & 13 & 0.87 & 18.87 & 0.76 & 0.98 & 19.521 & 0.7 & 17.6 \\
\hline $\mathrm{K} 271$ & $200-630$ & 13 & 0.87 & 22.52 & 0.72 & 0.89 & 17.830 & 0.4 & 17 \\
\hline K272 & $200-630$ & 13 & 0.87 & 23.52 & 0.94 & 1.08 & 21.616 & 0.8 & 18.4 \\
\hline K274a & $200-620$ & 13 & 0.89 & 16.86 & 0.86 & 0.82 & 16.436 & 0.6 & 20 \\
\hline K275a & $200-620$ & 13 & 0.87 & 26.56 & 0.85 & 0.87 & 17.389 & 0.4 & 18 \\
\hline $\mathrm{K} 276$ & $400-630$ & 11 & 0.89 & 37. & 0.61 & 0.77 & 15.400 & 0.2 & 17 \\
\hline $\mathrm{K} 277$ & $200-630$ & 13 & 0.87 & 26.35 & 0.71 & 0.81 & 16.137 & 0.3 & 18.2 \\
\hline К 279 & $200-630$ & 13 & 0.9 & 21.78 & 0.88 & 0.77 & 15.320 & 0.4 & 20 \\
\hline K281 & $300-630$ & 12 & 0.87 & 15.62 & 0.63 & 0.83 & 16.589 & 0.5 & 16.8 \\
\hline K282 & $300-630$ & 12 & 0.88 & 17.26 & 0.68 & 0.67 & 13.340 & 0.3 & 14 \\
\hline K283 & $200-630$ & 13 & 0.87 & 23.79 & 0.7 & 0.95 & 19.045 & 0.5 & 19 \\
\hline
\end{tabular}


Table 3. Average means of $H_{\text {anc }}$ ( \pm standard error of the means) obtained by the Thellier-Coe and Wilson methods, respectively, and associated VDMs. $n$ is the number of samples used for the Thellier-Coe determinations; $n_{\mathrm{W}}$ and $n_{\mathrm{T}}$ are the number of specimens used for paleointensity estimations by the Wilson and Thellier-Coe methods, respectively; $I_{\text {anc }}$ is the site-mean palaeoinclination. Note that VDMs are calculated only from the results of the Thellier-Coe method. $N$ is the number of samples used by Bol'shakov and Solodovnikov (1981a, 1983) to calculate the VDMs. Because there is no direct correspondence between our sampling units and those of Bol'shakov and Solodovnikov (1983), their Kafan values have been averaged out.

\begin{tabular}{|c|c|c|c|c|c|c|c|c|c|}
\hline \multirow{3}{*}{ Name of site } & \multicolumn{6}{|c|}{ This work } & \multicolumn{3}{|c|}{ Bol'shakov, Solodovnikov } \\
\hline & \multicolumn{2}{|c|}{ Wilson method } & \multicolumn{2}{|c|}{ Thellier-Coe method } & \multirow{2}{*}{$I_{\mathrm{anc}}$} & \multirow{2}{*}{$\mathrm{VDM} \times 10^{22} \mathrm{~A} \mathrm{~m}^{2}$} & \multirow{2}{*}{$\mathrm{VDM} \times 10^{22} \mathrm{~A} \mathrm{~m}^{2}$} & \multirow{2}{*}{$H_{\mathrm{anc}}, \mu \mathrm{T}$} & \multirow{2}{*}{$N$} \\
\hline & $n_{\mathrm{W}}$ & $H_{\mathrm{anc}}, \mu \mathrm{T}$ & $n / n_{\mathrm{T}}$ & $H_{\mathrm{anc}}, \mu \mathrm{T}$ & & & & & \\
\hline Tovuz-6 & 21 & $21.7 \pm 4.48$ & $17 / 36$ & $20.3 \pm 3$ & 40.3 & $4.34 \pm 0.56$ & $4.4 \pm 0.7$ & $22 \pm 4$ & 139 \\
\hline Paravakar-1 & 14 & $31.3 \pm 6.8$ & $16 / 23$ & $26.9 \pm 4.3$ & 45.5 & $5.47 \pm 0.86$ & $4.3 \pm 0.7$ & $22 \pm 4$ & 57 \\
\hline Kafan-1 & 17 & $11.3 \pm 2$ & $19 / 31$ & $10.1 \pm 2.4$ & 44.3 & $2.68 \pm 0.43$ & & & \\
\hline Kafan-2 & 9 & $7.54 \pm 1.2$ & $10 / 14$ & $7.0 \pm 1.3$ & 25.7 & $1.68 \pm 0.32$ & $3.0 \pm 0.9$ & $14 \pm 4$ & 184 \\
\hline Kafan-3 & 12 & $18 \pm 1.7$ & $12 / 12$ & $17.4 \pm 2.3$ & 45.5 & $3.53 \pm 0.43$ & & & \\
\hline
\end{tabular}

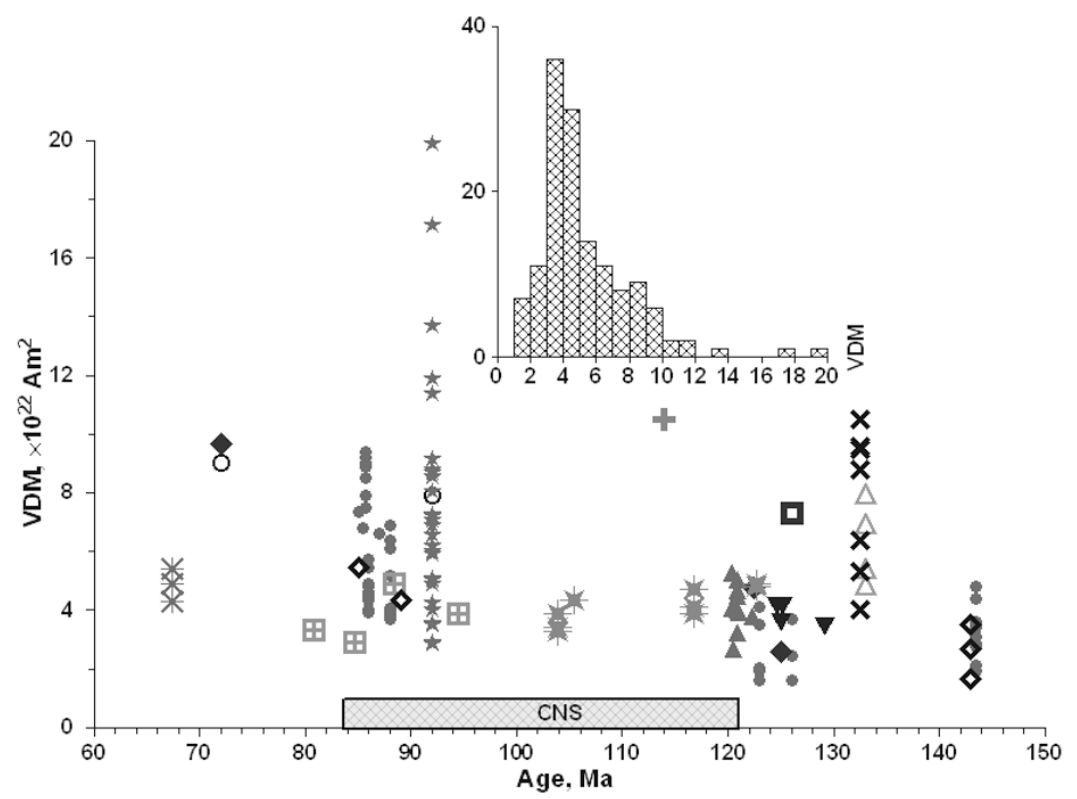

Bol'shakov and Solodovnikov (1981a, b, 1983), Solodovnikov (2001); ○ Juarez et al. (1998); $>$ Selkin and Tauxe (2000); + Cottrell and Tarduno (2000); $\Delta$ Zhu et al. (2001); $\mathbf{\nabla}$ Zhu et al. (2003); $\triangle$ Kosterov et al. (1998); × Goguitchaichvili et al. (2002); * Goguitchaichvili et al. (2004); $\star$ Tauxe and Staudigel (2004); $\times$ Zhu et al. (2004a, b, c); $\boxplus$ Shcherbakova et al. (2007); $\square$ Ruiz et al. (2006); $\diamond$ this work.

Fig. 11. Comparison of the paleointensity results obtained in this study with previously published Jurassic and Cretaceous results.

tion and pass through the origin of the orthogonal plot.

- The NRM fraction $f$ used in the linear fit represents at least $20 \%$ of the total NRM.

- The difference between initial pTRM acquisition and pTRM check normalized to the total NRM must be less than $5 \%$ within the given $\left(T_{1}, T_{2}\right)$ interval.

- The susceptibility remains constant within $10 \%$ in the $\left(T_{1}, T_{2}\right)$ range.

Most of these criteria are classical ones that have been used in previous studies (e.g., Yu and Dunlop, 2001; Heunemann et al., 2004; Yoshihara and Hamano, 2004). However, the first point, introduced to test the thermoremanent nature of NRM, is not so usual.

Of the nine sites studied (130 samples), only 40 samples from five contacts satisfied the paleointensity selection criteria formulated above: 17 samples from contact Tovuz 6 , 16 samples from contact Paravakar 1, and, respectively, 19, 10 , and 13 samples from contacts $\mathrm{K} 1, \mathrm{~K} 2$, and $\mathrm{K} 3$ from the Kafan section. This corresponds to a $30 \%$ success rate. Table 2 summarizes all of the Thellier palaeointensity deter- minations obtained from these rocks, with Coe's parameters $f, g$, and $q$ (Coe et al., 1978) introduced to characterize the technical quality of the obtained results: $f$ represents the fraction of NRM spanned by the linear fit; the gap factor $g$ quantifies the uniformity of the distribution of successive data points in a chosen temperature interval, in the ideal case of equidistant points $g=(N-2) /(N-1)$; the quality factor $q=k f g / \sigma$ is a way to quantify the reliability of a given palaeointensity determination ( $q \geq 5$, as proposed by Coe et al., 1978), with the coefficient $k=H_{\text {anc }} / H_{\text {lab }}$ (Table 2) being the tangent of the linear fit to the Arai-Nagata diagram and $\sigma$ its standard error. Because of the use of sister specimens, some samples appear more than once in Table 2 , and it can be seen that palaeointensity results obtained from sister specimens of a same sample with different devices usually agree well with each other.

Typical paleointensity diagrams obtained from these contacts are shown in Fig. 10. Whenever present, the low-temperature components are destroyed by $300-400^{\circ} \mathrm{C}$. Technically, the determinations made on the Armenian samples are very high quality, with a good linearity over a large 
fraction of NRM and reproducible pTRM checks (apart for the very high temperatures, which were not used in the calculation in any case). The high values $f>0.5$ associated with most of our intensity's determinations give a stronger line of support for a lack of MD bias in the results, as put forward by Biggin and Thomas (2003). However, the Paravakar 1 unit produces directions that are rather scattered $(k=38)$ and palaeointensity results which are of slightly poorer quality (lower $q$ and $f$ factors) than those of the Tovuz and Kafan units. On this basis and following Biggin and Thomas (2003), the Paravakar results should be treated more cautiously than the others.

Table 3 shows the average means of $H_{\text {anc }}$ obtained by the Thellier-Coe and Wilson methods, respectively. As seen, the results of the two methods correspond to each other rather well. The averaged virtual dipole moment (VDM) values are calculated only from the site-mean Thellier-type palaeointensities and site-mean palaeoinclinations $I_{\text {anc }}$. For comparison, data given by Bol'shakov and Solodovnikov are shown in the last three columns of Table 3.

\section{Discussion and Conclusions}

Paleomagnetic analysis of the Tovuz, Paravakar and Kafan sections (9 sites, 130 samples) was straightforward, with essentially one characteristic component of magnetization. The evidence for the primary origin of the ChRMs of these rocks is a good argument for considering these rocks for paleointensity experiments. Averaging data from the present study with those from previous works of Nguen (1978), Pechersky and Nguen (1978), and Bol'shakov and Solodovnikov (1981a, 1983), we defined updated mean paleomagnetic poles for the Upper Cretaceous Tovuz-Paravakar sections $\left(65.6^{\circ} \mathrm{N}, 162.2^{\circ} \mathrm{E}, A_{95}=\right.$ 4.3 , paleolatitude $=27.0 \pm 3.4^{\circ}$ ) and the Upper JurassicLower Cretaceous Kafan section $\left(61.7^{\circ} \mathrm{N}, 158.9^{\circ} \mathrm{E}, A_{95}=\right.$ $4.8^{\circ}$, paleolatitude $=24.7 \pm 3.8^{\circ}$ ).

Paleointensity determinations were estimated from two upper Cretaceous baked contacts sampled in northern Armenia and three Upper Jurassic-Lower Cretaceous baked contacts from southern Armenia. Only 30\% of the overall collection fulfilled our selection criteria. The mean VDM obtained in this paper are low (1.7-5.5 $\left.\times 10^{22} \mathrm{~A} \mathrm{~m}^{2}\right)$ and in agreement with data published earlier by Bol'shakov and Solodovnikov $(1981 \mathrm{a}, 1983)$ for the same sections (3.0$4.4 \times 10^{22} \mathrm{~A} \mathrm{~m}^{2}$ ). Thus, the results of our study support their data, at least for the sections described in this paper. It is worth remembering that another set of Solodovnikov data (Solodovnikov, 1995) on the Permian-Triassic Norilsk traps have been recently re-analyzed by Heinemann et al. (2004) and Shcherbakova et al. (2005). Again a good general agreement was found between both sets of data for the Permian-Triassic boundary.

The results obtained here (Table 3) still favor the hypothesis of a Low Mezozoic Dipole as suggested by Prévot et al. (1990) and Perrin et al. (1991). Figure 11 presents palaeointensity data for the period 60-150 Ma that satisfy reliability criteria similar to the ones formulated by Perrin and Shcherbakov (1997): only Thellier-type determinations are considered; at least three samples are used for the VDM calculation; an error on the estimate of the mean should not exceed $10 \%$ (the criterion of internal consistency). A total of 134 Thellier-type palaeointensity determinations were found to pass this selection for the 60-150 Ma period, and most of the data lie below the line VDM $=8 \times 10^{22} \mathrm{~A} \mathrm{~m}^{2}$ depicting the modern Earth VDM value. To look briefly at the statistics, the inset to Fig. 11 shows a histogram of VDM selected for this Late Jurassic-Cretaceous interval. A large majority of the data belongs to the $3-5 \times 10^{22} \mathrm{~A} \mathrm{~m}^{2}$ interval, which is in perfect agreement with values proposed earlier by Perrin and Shcherbakov (1997).

Acknowledgments. The authors are grateful to Andy Biggin and an anonymous referee for the valuable comments made to this paper. This work was supported by the INTAS grant 03-51-5807 and Russian Fund of Basic Researches, grant No. 06-05-64538.

\section{References}

Avanesyan, A. S. and M. A. Avanesyan, Tectonic zonation of Armenia, in Investigation of geological conditions of possible sites for radioactive waste disposal, edited by Gukasyan, Yu A., Funds of Institute of Geological Research Armenian National Academy of Science, 2006 (in Armenian).

Biggin, A. and D. N. Thomas, The application of acceptance criteria to results of Thellier palaeointensity experiments performed on samples with pseudo-single-domain-like characteristics, Phys. Earth Planet. Inter., 138, 279-287, 2003.

Bol'shakov, A. S. and G. M. Solodovnikov, Intensity of the geomagnetic field in Late Cretaceous time, Izv. Earth Phys., 17, 754-761, 1981a.

Bol'shakov, A. S. and G. M. Solodovnikov, Geomagnetic field intensity in last 400 million years, Doklady AS USSR, 260(6), 1340-1343, 1981b.

Bol'shakov, A. S. and G. M. Solodovnikov, Geomagnetic field intensity in Armenia in the Late Jurassic and Early Cretaceous, Izv. Earth Phys., 19, 976-982, 1983.

Chubaryan, H. A. and M. A. Arakelyan, Geological structure of the watershed of middle streams of Agstev and Mehrab rivers, Summary report, Armenian Geological Funds, Yerevan, 1962 (in Armenian).

Coe, R. S., The determination of paleointensities of the Earth magnetic field with special emphasize on mechanisms which could cause nonideal behavior in Thellier method, J. Geomag. Geoelectr., 19, 157-179, 1967.

Coe, R. S., C. S. Gromme, and E. A. Mankinen, Geomagnetic paleointensities from radiocarbon-dated lava flows on Hawaii and the question of the Pacific nondipole low, J. Geophys. Res., 83, 1740-1756, 1978.

Cottrell, R. D. and J. A. Tarduno, In search of high-fidelity geomagnetic paleointensities: A comparison of single plagioclase crystal and whole rock Thellier-Thellier analyses, J. Geophys. Res., 105, 23,579-23,594, 2000

Day, R. S., M. Fuller, and V. A. Schmidt, Hysteresis properties of titanomagnetites: grain size and composition dependence, Phys. Earth Planet. Inter., 13, 260-267, 1977.

Dunlop, D. and O. Ozdemir, Rock magnetism. Fundamentals and frontiers, Cambridge University Press, 573 pp., 1997.

Gendler, T. S., V. P. Shcherbakov, M. J. Dekkers, A. K. Gapeev, S. K. Gribov, and E. McClelland, The lepidocrocite-maghemite-haematite reaction chain-I. Acquisition of chemical remanent magnetization by maghemite, its magnetic properties and thermal stability, Geophys. $J$. Int., 160, 815-832, 2005.

Goguitchaichvili, A., L. M. Alva-Valdivia, J. Urrutia, J. Morales, and O. F. Lopes, On the reliability of Mesozoic Dipole Low: New absolute paleointensity results from Parana Flood Basalts (Brazil), Geophys. Res. Lett., 29, 331-334, 2002.

Goguitchaichvili, A., L. M. Alva-Valdivia, J. Rosas-Elguera, J. UrrutiaFucugauchi, and J. Sole, Absolute geomagnetic paleointensity after the Cretaceous Normal Superchron and just prior the Cretaceous-Tertiary transition, J. Geophys. Res., 109, B01105, 2004.

Hakobyan, V. T., Stratigraphy of Jurassic and Cretaceous sedimentary rocks of the north-eastern part of Zangezour, Academy of Science Armenian SSR. Yerevan, 1963 (in Russian).

Heunemann, C., D. Krasa, E. L. Gurevitch, H. C. Soffel, and V. Bachtadse, Directions and intensities of the Earth's magnetic field during a reversal: results form the Permo-Triassic Siberian trap basalts, Russia, Earth Planet. Sci. Lett., 218, 197-213, 2004.

Johnson, H. P. and R. T. Merrill, Low-temperature oxidation of a titano- 
magnetite and the implication for palaeomagnetism, J. Geophys. Res., 78, 4938-4949, 1973.

Juarez, M. T., L. Tauxe, J. S. Gee, and T. Pick, The intensity of the Earth's magnetic field over the past 160 million years, Nature, 394, 878-881, 1998 .

Khramov, A. N._ed., Paleomagnetic Directions and Paleomagnetic Poles: Data for USSR, Issue 3. Materials of the WDC-B, Moscow, 44 pp., 1975 (in Russian).

Khramov, A. N., Paleomagnetic Directions and Paleomagnetic Poles, Data for USSR, Issue 6. Materials of the WDC-B, Moscow, 39 pp., 1986 (in Russian).

Khramov, A. N., Paleomagnetic Directions and Paleomagnetic Poles, Data for USSR, Issue 7. Materials of the WDC-B, Moscow, 29 pp., 1989 (in Russian).

Kobayashi, K., Crystallization or chemical remanent magnetization, Proc. Benedum Earth Magnetism Symp., University of Pittsburg, 107-112, 1962.

Kosterov, A. A., M. Perrin, J. M. Glen, and R. S. Coe, Paleointensity of the Earth's magnetic field in early Cretaceous time: the Parana basalt, Brazil, J. Geophys. Res., 103, 9739-9753, 1998.

McElhinny, M. W. and P. L. McFadden, Paleomagnetism: continents and oceans, Int. Geophys. Ser., 73, Academic, San Diego, Calif., 386 pp., 2000.

McFadden, P. L. and M. W. McElhinny, Classification of reversal test in paleomagnetism, Geophys. J. Int., 103, 725-729, 1990.

Nguen, T. K. T., The substantiation of the reliability of the paleomagnetic data under the solving of the paleotectonic tasks, $\mathrm{PhD}$ Thesis dissertation, Institute of Earth Physics, Moscow, 1978 (in Russian).

Pechersky, D. M. and T. K. T. Nguen, Paleomagnetism of volcanites of the Ophiolite Series and Late Cretaceous Effusive Rocks of Armenia, Izv. Earth Phys., 14, 192-202, 1978.

Perrin, M. and V. P. Shcherbakov, Paleointensity of the Earth's Magnetic Field for the Past 400 Ma: Evidence for a Dipole Structure during the Mesozoic Low, J. Geomag. Geoelectr., 49, 601-614, 1997.

Perrin, M. and E. Schnepp, IAGA Paleointensity database: Distribution and quality of the data set, Phys. Earth Planet. Inter., 147, 255-267, 2004.

Perrin, M., M. Prevot, and E. A. Mankinen, Low Intensity of the Geomagnetic Field in Early Jurassic Time, J. Geophys. Res., 96(B9), 14,19714,210, 1991.

Perrin, M., E. Schnepp, and V. P. Shcherbakov, Paleointensity database updated, Eos Trans. AGU, 79, 1998.

Prévot, M., M. E. Derder, M. McWilliams, and J. Thompson, Intensity of the Earth's magnetic field: evidence for a Mesozoic dipole low, Earth Planet. Sci. Lett., 97, 129-139, 1990

Ruiz, R. C., A. Goguitchaichvili, S. E. Geuna, L. M. Alva-Valdivia, J. Solé, and J. Morales, Early cretaceous absolute geomagnetic paleointensities from Córdoba Province (Argentina), Earth Planets Space, 58, 13331339, 2006.

Selkin, P. A. and L. Tauxe, Long-term variations in palaeointensity, Philos Trans. R. Soc. Lond. A, 358, 1065-1088, 2000.

Shcherbakov, V. P. and N. K. Sycheva, On the Variation in the Geomagnetic Dipole over the Geologocal History of the Earth, Izv. Phys. Solid Earth, 42(3), 201-206, 2006.

Shcherbakov, V. P., B. E. Lamash, and N. K. Sycheva, Monte-Carlo modeling of TRM and CRM acquisition and comparison of their properties in an ensemble of interacting SD grains, Geophys. Res. Lett., 23(20), 2827-2830, 1996.

Shcherbakov, V. P., V. V. Shcherbakova, Y. K. Vinogradov, and F. Heider, Thermal stability of pTRMs created from different magnetic states, Phys. Earth Planet. Inter., 126(1-2), 59-73, 2001.

Shcherbakova, V. V., V. P. Shcherbakov, and F. Heider, Properties of partial thermoremanent magnetization in PSD and MD magnetite grains, $J$.
Geophys. Res., 105(B1), 767-782, 2000.

Shcherbakova, V. V., V. P. Shcherbakov, V. V. Vodovozov, and N. K. Sycheva, Paleointensity at the Permian-Triassic Boundary and in the Late Permian, Izv. Phys. Solid Earth, 41(11), 931-944, 2005.

Shcherbakova, V. V., B. Z. Asanidze, V. P. Shcherbakov, and G. V. Zhidkov, Geomagnetic Field Paleointensity in the Cretaceous from Upper Cretaceous Rocks of Georgia, Izv. Phys. Solid Earth, 43(11), 951-959, 2007

Shmidt, A. I., H. H. Tonakanyan, A. S. Avanesyan et al., Compiling of predictive-metallogenic map of northern part of Armenia at scale 1:50 000, lists K-38-115 B,G,V-b,V-g, K-38-116 A-v,B-a, Summary report, Armenian Geological Funds, Yerevan, 1982 (in Russian).

Smirnov, A. V. and J. A. Tarduno, Thermochemical remanent magnetization in Precambria rocks Are we sure the geomagnetic field was weak?, J. Geophys. Res., 110, B06103, doi:10.1029/2004JB003445, 2005.

Solodovnikov, G. M., Palaeointensity of the Early Triassic geomagnetic field, Izv. Phys. Solid Earth, 30, 815-821, 1995

Solodovnikov, G. M., Determination of the geomagnetic field intensity in the Santonian-Coniacian (Upper Cretaceous) from an Effusive Section in Azerbaijan, Izv. Phys. Solid Earth, 87, 600-606, 2001.

Stacey, F. D. and S. K. Banerjee, The Physical Principles of Rock Magnetism, 195 pp., Elsevier, New York, 1974.

Tarduno, J. A. and R. D. Cottrell, Dipole strength and variation of the time-averaged reversing and nonreversing geodynamo based on Thellier analyses of single plagioclase crystals, J. Geophys. Res., 110, B11101, doi:10.1029/2005JB003970, 2005.

Tauxe, L. and H. Staudigel, Strength of the geomagnetic field in the Cretaceous Normal Superchron: New data from submarine basaltic glass of the Troodos Ophiolite, Geochem. Geophys. Geosyst., 5, 26-41, 2004.

Thellier, E. and O. Thellier, Sur l'intensité du champ magnétique terrestre dans le passé historique et géologique, Ann. Geophys., 15, 285-376, 1959.

Uspenskaya, E. A., L. A. Burshteyn, and E. Y. Leven, Compiling of geological-structural basis at scale 1:50 000 for predactive-metallogenic map of Zangezour-Kapan Ore Zone, Armenian Geological Funds, Yerevan, 1984 (in Russian).

Yoshihara, A. and Y. Hamano, Palaeointensities determined from the middle Cretaceous basalt in Liaoning Province, northeastern China, Phys. Earth Planet. Inter., 142, 49-59, 2004.

Yu, Y. and D. J. Dunlop, Palaeointensity determination on the late Precambrian Tudor gabbro, Ontario, J. Geophys. Res., 106(B11), 26,33126,348, 2001.

Zhu, R., Y. Pan, J. Shaw, D. Li, and Q. Li, Geomagnetic palaeointensity just prior to the Cretaceous normal superchron, Phys. Earth Planet. Inter., 128, 207-222, 2001.

Zhu, R., K. A. Hoffman, Y. Pan, R. Shi, and D. Li, Evidence for weak geomagnetic field intensity prior to the Cretaceous normal superchron, Phys. Earth Planet. Inter., 136, 187-199, 2003.

Zhu, R., C.-H. Lo, R. Shi, Y. Pan, G. Shi, and J. Shao, Is there a precursor to the Cretaceous normal superchron? New paleointensity and age determination from Liaoning province, northeastern China, Phys. Earth Planet. Inter., 147, 117-126, 2004a.

Zhu, R., K. A. Hoffman, S. Nomade, P. R. Renne, R. Shi, Y. Pan, and G. Shi, Geomagnetic paleointensity and direct age determination of the ISEA (M0r?) chron, Earth Planet. Sci. Lett., 217, 285-295, 2004b.

Zhu, R., C.-H. Lo, R. Shi, G. Shi, Y. Pan, and J. Shao, Palaeointensities determined from the middle Cretaceous basalt in Liaoning Province, northeastern China, Phys. Earth Planet. Inter., 142, 49-59, 2004c.

V. V. Shcherbakova, M. Perrin, V. P. Shcherbakov (e-mail: shcherb@borok.yar.ru), V. E. Pavlov, A. Ayvaz’yan, and G. V. Zhidkov 